Article

\title{
Experimental and Kinetic Studies on Steam Gasification of a Biomass Char
}

\author{
Shengguo Zhao, Liang Ding *(D), Yun Ruan, Bin Bai, Zegang Qiu and Zhiqin Li \\ College of Chemistry and Chemical Engineering, Xi'an Shiyou University, Xi'an 710065, China; \\ siwuxie112zsg@163.com (S.Z.); ruanyun001@163.com (Y.R.); bai187917841042021@163.com (B.B.); \\ qiuzegang@xsyu.edu.cn (Z.Q.); lizhiqin@xsyu.edu.cn (Z.L.) \\ * Correspondence: dingliang6000@xsyu.edu.cn
}

check for updates

Citation: Zhao, S.; Ding, L.; Ruan, Y.; Bai, B.; Qiu, Z.; Li, Z. Experimental and Kinetic Studies on Steam Gasification of a Biomass Char. Energies 2021, 14, 7229. https:// doi.org/10.3390/en14217229

Academic Editors: Paolo Defilippis and Mejdi Jeguirim

Received: 22 September 2021

Accepted: 29 October 2021

Published: 2 November 2021

Publisher's Note: MDPI stays neutral with regard to jurisdictional claims in published maps and institutional affiliations.

Copyright: (C) 2021 by the authors. Licensee MDPI, Basel, Switzerland. This article is an open access article distributed under the terms and conditions of the Creative Commons Attribution (CC BY) license (https:/ / creativecommons.org/licenses/by/ $4.0 /)$.

\begin{abstract}
The maximum gasification rate of corn stalk char (CSC) appeared at high conversion range, and its quite different gasification behaviors from other carbonaceous materials are all derived from the catalytic effect of alkali and alkali earth metals (AAEMs), so it is necessary to study the effect of AAEMs and gasification kinetics of such biomass char. However, there are few systematic discussions about this effect and kinetic modeling. Thus, in this study, CSC samples were prepared in a fast pyrolysis fixed-bed reactor, and its gasification experiments were conducted on a pressurized magnetic suspension balance at various total pressures (0.1-0.7 MPa), steam concentrations (10-70 vol.\%) and temperatures $\left(725-900{ }^{\circ} \mathrm{C}\right)$. Moreover, a water-leached CSC $\left(\mathrm{H}_{2} \mathrm{O}-\mathrm{CSC}\right)$ was also prepared to evaluate the impact of AAEMs on the gasification performance of CSC, and some well-known models were adopted to describe the gasification behaviors. On the basis of these results, the effect of primary AAEMs on the gasification behaviors of CSC and gasification kinetic modeling were obtained. Results showed total pressure had no obvious influence on the gasification rate of CSC, and the reaction order varied at $0.43-0.55$ with respect to steam partial pressures. In addition, the modified random pore model (MRPM) and Langmuir-Hinshelwood (L-H) model were satisfactorily applied to predict the gasification behaviors of CSC. The catalytic effect of AAEMs on CSC gasification was weakened due to water-leaching treatment. A random pore model (RPM) could describe the gasification behavior of $\mathrm{H}_{2} \mathrm{O}-\mathrm{CSC}$ well, followed by grain model (GM) and volumetric model (VM).
\end{abstract}

Keywords: biomass char; steam gasification; kinetic model; AAEMs

\section{Introduction}

Accompanied with the huge consumption of fossil fuels (especially coal) and the induced serious environmental problems, in recent years, the usage of biomass resource has attracted lots of attention. Compared with coal, biomass has some advantages, e.g., it is carbon-dioxide-neutral, renewable and has high gasification reactivity as well as low $\mathrm{S}$ and $\mathrm{N}$ content, thus becoming a reasonable alternative energy. Among the methods of thermal processing biomass resources, biomass gasification can produce syngas for liquid fuels and chemical productions and is considered as a promising technology [1,2].

Gasification of biomass includes two main steps: (1) pyrolysis of the raw samples and (2) gasification of the residual chars. Compared with pyrolysis, the reaction rate of char is rather slow; therefore, it is considered to be the kinetic controlling step of gasification. In industrial applications, it is important to know how fast the reaction proceeds and how long it will take to complete char conversion. Therefore, the research on biomass char gasification kinetics is crucial for the simulation of gasification process and design of the gasifiers [3,4].

Many works have been done on the gasification reactions of biomass char with steam, $\mathrm{CO}_{2}$ or steam $/ \mathrm{CO}_{2}$. Results concerning the effects of the biomass char prepared conditions such as pyrolysis temperature [5-8], pressure [9,10], heating rate [11,12], atmosphere [13] and sample size [8] on biomass char gasification reactivity, which are summarized in 
Table 1. In addition, further research focused on the effects of alkali and alkali earth metals (AAEMs) on biomass char gasification behaviors [14-21] are shown in Table 2. Generally, $\mathrm{K}, \mathrm{Na}$ and $\mathrm{Ca}$ have been found to remarkably increase the gasification rate of biomass char, of which the catalytic effect of $\mathrm{K}$ is the most prominent one. Biomass and biomass char are usually rich in AAEMs [19,20,22]. Attributed to the high amount of AAEMs, the gasification behavior of biomass char differs a lot from coal char. For example, the maximum gasification rate of some biomass chars always appeared at high conversion range [19,23-25]; however, the maximum gasification rate of coal char was usually at low conversion range [26-29]. Thus, the conventional $n$ th-order model such as volumetric model (VM), grain model (GM) and random pore model (RPM) can no longer predict the gasification behaviors of these kinds of biomass chars [19,24]. Owing to Zhang and his co-workers' efforts [19], a semi-empirical model based on random pore model (which is known as modified random pore model (MRPM)) was proposed to solve this problem, and this model could describe the experimental data of 14 biomass chars well over the whole conversion range. This model is especially suitable for biomass char that has a maximum gasification rate at high carbon conversion range ( $>0.393)$. MRPM has been proved to be successful in describing the gasification behaviors of biomass chars $[7,15,19,24]$. Although AAEMs (whether loaded on biomass chars or indigenous) were proved to increase the gasification rate of biomass chars and lead to a maximum reaction rate showing at a high conversion range $[15,17]$, the discussions about the effect of AAEMs on kinetic modeling of biomass char are few $[15,30]$. Despite the $n$ th-order model, the Langmuir-Hinshelwood model (L-H) model based on the stepwise reaction mechanism which can give the relations between gasification rate and reactant partial pressure was usually applied to predict the gasification behaviors and determine the kinetic parameters of char [31,32].

This work aims to study the gasification kinetics of biomass char rich in AAEMs (especially $\mathrm{K}$ ) under steam atmosphere and adopt an applicable model to describe the experimental results. The $n$ th-order model and L-H model were used to predict the gasification behaviors of biomass char and obtain the corresponding kinetic parameters. Furthermore, an attempt was made to evaluate the effects of indigenous AAEMs on biomass char gasification rate and kinetic model. In order to study the mentioned issues, a fast pyrolysis biomass char was made and gasified in a thermogravimetric analyzer. For the purpose of investigating the effect of indigenous AAEMs on the gasification behaviors of biomass char, a water-leached biomass char was also prepared. 
Table 1. Summary on the effect of char prepared conditions on the reactivities of biomass chars.

\begin{tabular}{|c|c|c|c|c|}
\hline Reference & Materials & $\begin{array}{c}\text { Pyrolysis Conditions } \\
\text { [Temperature (T); Atmosphere; Pressure; } \\
\text { Heating Rate (HR); Retention Time }(t) ; \\
\text { Reactor; etc.] }\end{array}$ & $\begin{array}{l}\text { Gasification Conditions } \\
\text { [Temperature (T); Agents; } \\
\text { Pressure; Reactor; etc.] }\end{array}$ & Key Findings \\
\hline Gao et al. [5] & rice husk & $\begin{array}{l}\mathrm{T}=700-900^{\circ} \mathrm{C} ; \mathrm{N}_{2}, 1000 \mathrm{~mL} / \mathrm{min} ; \\
\text { atmospheric pressure; HR: not available; } \\
t=3 \text { min; micro quartz reactor }\end{array}$ & $\begin{array}{c}\mathrm{T}=850-950{ }^{\circ} \mathrm{C} ; \mathrm{CO}_{2} \\
100 \mathrm{~mL} / \mathrm{min} ; \text { atmospheric } \\
\text { pressure; TGA }\end{array}$ & $\begin{array}{l}\text { 1. Reaction order increased as the pyrolysis } \\
\text { temperature increased. } \\
\text { 2. Pyrolysis temperature had slight effect on } \\
\text { the intrinsic activation energy but led to a } \\
\text { decrease in the pre-exponential factor. }\end{array}$ \\
\hline Lin et al. [6] & wood, miscanthus, straw & $\begin{array}{c}T=600-800{ }^{\circ} \mathrm{C} ; \mathrm{N}_{2} ; \text { atmospheric pressure; } \\
\text { HR: not available; } t=3,5,15 \mathrm{~min} ; \\
\text { tubular reactor }\end{array}$ & $\begin{array}{c}T=800-900{ }^{\circ} \mathrm{C}(\mathrm{TGA}) \\
1100-1300{ }^{\circ} \mathrm{C} \text { (aerosol reactor); } \\
\mathrm{CO}_{2}(33 \text { vol. } \%)+\mathrm{N}_{2} \\
150 \mathrm{~mL} / \mathrm{min} ; \text { atmospheric } \\
\text { pressure; TGA and } \\
\text { aerosol reactor }\end{array}$ & $\begin{array}{l}\text { reactivity at low temperatures. } \\
\text { 2. At higher temperatures, for wood char, the } \\
\text { reactivities of short retention time were } \\
\text { higher than long retention time. For } \\
\text { miscanthus and straw chars made within } \\
\text { same retention time, pyrolysis temperature } \\
\text { had no clear effect on the reactivity. }\end{array}$ \\
\hline Chew et al. [7] & oil palm biomass, $<0.25 \mathrm{~mm}$ & $\begin{array}{c}\mathrm{T}=280^{\circ} \mathrm{C}(t=120 \mathrm{~min}), 300^{\circ} \mathrm{C}(t=30 \mathrm{~min}) \\
\mathrm{N}_{2}, 150 \mathrm{~mL} / \mathrm{min} ; \text { atmospheric pressure; } \\
\mathrm{HR}=10^{\circ} \mathrm{C} / \mathrm{min} \text {; vertical fixed-bed reactor }\end{array}$ & $\begin{array}{l}\mathrm{T}=800-900^{\circ} \mathrm{C} ; \mathrm{CO}_{2} ; \\
\text { atmospheric pressure; TGA }\end{array}$ & $\begin{array}{l}\text { Average reactivity index of three kinds of oil } \\
\text { palm biomass reduced due to torrefaction. }\end{array}$ \\
\hline Strandberg et al. [8] & $\begin{array}{l}\text { scots pine, wheat straw, } \\
125-150 \mu \mathrm{m} ; 400-425 \mu \mathrm{m} ; \\
600-630 \mu \mathrm{m}\end{array}$ & $\begin{array}{l}T=900,1100{ }^{\circ} \mathrm{C} ; \mathrm{N}_{2} \text {, primary gas } 380 \\
\mathrm{~mL} / \mathrm{min} \text {, secondary carrier gas } 5000 \mathrm{~mL} / \mathrm{min} ; \\
\text { atmospheric pressure; } \mathrm{HR}=800-1000{ }^{\circ} \mathrm{C} / \mathrm{s} ; \\
t: \text { not available; drop tube furnace }\end{array}$ & $\begin{array}{c}\mathrm{T}=700-900{ }^{\circ} \mathrm{C} ; \mathrm{CO}_{2}(20 \text { vol. } \%)+ \\
\mathrm{N}_{2}, 100 \mathrm{~mL} / \mathrm{min} ; \text { atmospheric } \\
\text { pressure; TGA }\end{array}$ & $\begin{array}{l}\text { 1. Pyrolysis temperature had no obvious } \\
\text { effect on char reactivity. } \\
\text { 2. Char produced from smaller pine wood } \\
\text { particles had higher reactivity, while wheat } \\
\text { straw char showed less dependence on initial } \\
\text { particle size. }\end{array}$ \\
\hline Cetin et al. [9] & $\begin{array}{c}\text { radiata pine, spotted gum, } \\
\text { sugarcane bagasse, } 180-350 \\
\mu \mathrm{m} \text { and } 1-2 \mathrm{~mm}\end{array}$ & $\begin{array}{c}\text { 1. } T=950{ }^{\circ} \mathrm{C} ; \mathrm{N}_{2}, 2.0 \mathrm{MPa} ; \mathrm{HR}=500{ }^{\circ} \mathrm{C} / \mathrm{s} ; \\
\quad t=20 \mathrm{~s} ; \text { wire-mesh reactor } \\
\text { 2. } T=950{ }^{\circ} \mathrm{C} ; \mathrm{N}_{2} ; \text { atmospheric pressure; } \\
\mathrm{HR}=20^{\circ} \mathrm{C} / \mathrm{s} ; t=5 \mathrm{~min} ; \text { tubular reactor }\end{array}$ & $\begin{array}{c}\text { 1. } \mathrm{T}=800-1050{ }^{\circ} \mathrm{C} ; \mathrm{CO}_{2} ; \\
\text { atmospheric pressure; } \mathrm{TGA} \\
2 . \mathrm{T}=800-900{ }^{\circ} \mathrm{C} ; \mathrm{CO}_{2} ; \\
\text { atmospheric pressure; tubular } \\
\text { reactor } \\
\text { 3. } \mathrm{T}=800-900{ }^{\circ} \mathrm{C} ; \mathrm{CO}_{2} \\
(20-100 \text { vol. } \%)+\mathrm{N}_{2} ; 0.5-2.0 \\
\mathrm{MPa} ; \text { high-pressure } \\
\text { thermogravimetric analyzer }\end{array}$ & $\begin{array}{l}\text { Global char gasification reactivity decreased } \\
\text { with increasing pyrolysis pressure. }\end{array}$ \\
\hline
\end{tabular}


Table 1. Cont.

\begin{tabular}{|c|c|c|c|c|}
\hline Reference & Materials & $\begin{array}{c}\text { Pyrolysis Conditions } \\
\text { [Temperature (T); Atmosphere; Pressure; } \\
\text { Heating Rate (HR); Retention Time }(t) ; \\
\text { Reactor; etc.] }\end{array}$ & $\begin{array}{l}\text { Gasification Conditions } \\
\text { [Temperature (T); Agents; } \\
\text { Pressure; Reactor; etc.] }\end{array}$ & Key Findings \\
\hline Okumura et al. [10] & Douglas fir & $\begin{array}{c}\mathrm{T}=800{ }^{\circ} \mathrm{C} ; \mathrm{N}_{2}, 100 \mathrm{~mL} / \mathrm{min} ; 0.1-3.0 \mathrm{MPa} \\
\mathrm{HR}=15-600^{\circ} \mathrm{C} / \mathrm{s} ; \text { t } \text { not available; } \\
\text { not available }\end{array}$ & $\begin{array}{c}T=700-1100{ }^{\circ} \mathrm{C} ; \mathrm{CO}_{2} ; \\
\text { atmospheric pressure; TGA }\end{array}$ & $\begin{array}{l}\text { 1. Increased pyrolysis pressure led to a } \\
\text { decrease in char reactivity. } \\
\text { 2. High pyrolysis heating rate led to an } \\
\text { increase in char reactivity. }\end{array}$ \\
\hline Septien et al. [11] & beech woodchips & 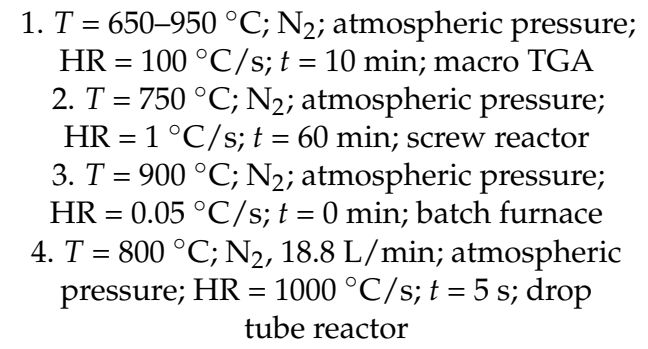 & $\begin{array}{c}\mathrm{T}=750-950{ }^{\circ} \mathrm{C} ; \mathrm{H}_{2} \mathrm{O}(15-50 \\
\text { vol. } \%)+\mathrm{N}_{2}, 11.8-14.2 \mathrm{~L} / \mathrm{min} ; \\
\text { atmospheric pressure; } \\
\text { macro TGA }\end{array}$ & $\begin{array}{l}\text { 1. Char reactivity increased with pyrolysis } \\
\text { heating rate. } \\
\text { 2. Among the high heating rate chars, the } \\
\text { reactivity increased with pyrolysis } \\
\text { temperature; among the low heating rating } \\
\text { samples, no significant difference } \\
\text { was observed. }\end{array}$ \\
\hline Dahou et al. [12] & $\begin{array}{l}\text { rice husk, wheat straw, apple } \\
\text { orchard residue, apricot } \\
\text { orchard residue, vineyard } \\
\text { residue, sunflower seed } \\
\text { shells, alfalfa }\end{array}$ & $\begin{array}{l}\text { 1. } T=450{ }^{\circ} \mathrm{C} ; \mathrm{N}_{2}, 1000 \mathrm{~mL} / \mathrm{min} ; \text { atmospheric } \\
\text { pressure; } \mathrm{HR}=10{ }^{\circ} \mathrm{C} / \mathrm{s} ; t=60 \mathrm{~min} ; \\
\text { fixed-bed reactor } \\
\text { 2. } \mathrm{T}=800^{\circ} \mathrm{C} ; \mathrm{N}_{2}, 1000 \mathrm{~mL} / \mathrm{min} \text {; atmospheric } \\
\text { pressure; } \mathrm{HR}=24{ }^{\circ} \mathrm{C} / \mathrm{s} ; t=60 \mathrm{~min} ; \text { induction } \\
\text { vertical reactor } \\
\text { 3. } T=800{ }^{\circ} \mathrm{C} ; \mathrm{N}_{2}, 1000 \mathrm{~mL} / \mathrm{min} ; \text { atmospheric } \\
\text { pressure; } \mathrm{HR}=24{ }^{\circ} \mathrm{C} / \mathrm{s} ; t=30 \mathrm{~min} ; \mathrm{TGA}\end{array}$ & $\begin{array}{c}T=800{ }^{\circ} \mathrm{C} ; \mathrm{H}_{2} \mathrm{O}(20 \text { vol. } \%)+\mathrm{N}_{2} \\
50 \mathrm{~mL} / \mathrm{min} ; \text { atmospheric } \\
\text { pressure; TGA }\end{array}$ & $\begin{array}{l}\text { Char prepared in different conditions had the } \\
\text { same reactivity during gasification. }\end{array}$ \\
\hline Xiao et al. [13] & rice straw, $0.180-0.425 \mathrm{~mm}$ & $\begin{array}{c}T=300-600{ }^{\circ} \mathrm{C} ; \mathrm{N}_{2}, \mathrm{H}_{2}, \mathrm{CO}_{2}, 350 \mathrm{~mL} / \mathrm{min} ; \\
\text { atmospheric pressure; } \mathrm{HR}=5^{\circ} \mathrm{C} / \mathrm{s} ; t=90 \\
\text { min; tubular reactor }\end{array}$ & $\begin{array}{c}T=900-1050{ }^{\circ} \mathrm{C} ; \mathrm{CO}_{2} ; \\
\text { atmospheric pressure; TGA }\end{array}$ & $\begin{array}{l}\text { 1. Char reactivity increased with pyrolysis } \\
\text { temperature and reached a maximum at } \\
400{ }^{\circ} \mathrm{C} \text { then decreased. } \\
\text { 2. Reactivity of char under different pyrolysis } \\
\text { atmosphere was in the order of: } \\
\qquad \mathrm{H}_{2}>\mathrm{N}_{2}>\mathrm{CO}_{2} .\end{array}$ \\
\hline
\end{tabular}


Table 2. Summary on the effect of AAEMs on the gasification behaviors of biomass chars.

\begin{tabular}{|c|c|c|c|c|c|}
\hline Reference & Materials & $\begin{array}{l}\text { Catalyst Type, Ratio and } \\
\text { Loading Methods }\end{array}$ & $\begin{array}{c}\text { Char Preparation } \\
\text { Conditions } \\
\text { [Temperature }(T) ; \\
\text { Atmosphere; Pressure; } \\
\text { Heating Rate }(\mathrm{HR}) ; \\
\text { Retention Time }(t) ; \\
\text { Reactor; etc.] }\end{array}$ & $\begin{array}{l}\text { Gasification Conditions } \\
\text { [Temperature; Agents; } \\
\text { Pressure; Reactor; etc.] }\end{array}$ & Key Findings \\
\hline Feng et al. [14] & $\begin{array}{c}\text { Manchurian walnut } \\
\text { sawdust, } \\
0.15-0.25 \mathrm{~mm}\end{array}$ & $\begin{array}{l}\text { Inherent AAEMs and investigated by } \\
\text { chemical fractionation analysis. }\end{array}$ & $\begin{array}{c}T=800{ }^{\circ} \mathrm{C} ; \mathrm{N}_{2}, 5700 \mathrm{~mL} / \mathrm{min} ; \\
\text { atmospheric pressure; } \mathrm{HR}: \\
\text { not available; } t=4.2 \mathrm{~s} ; \\
\text { entrained-flow reactor }\end{array}$ & $\begin{array}{c}T=800{ }^{\circ} \mathrm{C} ; \mathrm{H}_{2} \mathrm{O}(15 \text { vol. } \%)+ \\
\mathrm{N}_{2} ; \text { atmospheric pressure; } \\
\text { fluidized bed / fixed-bed } \\
\text { reactor }\end{array}$ & $\begin{array}{l}\mathrm{H}_{2} \mathrm{O} \text {-soluble AAEMs were important } \\
\text { in determining the highest reactivity } \\
\text { of char. The effect of } \mathrm{NH}_{4} \mathrm{Ac} \text {-soluble } \\
\text { AAEMs on char activity was mainly } \\
\text { concentrated in the high carbon } \\
\text { conversion stage, and that of } \\
\mathrm{HCl} \text {-soluble AAEMs was reflected in } \\
\text { the whole testing stage. }\end{array}$ \\
\hline Kirtania et al. [15] & pine sawdust & $\begin{array}{c}\text { Solutions of } \mathrm{K}_{2} \mathrm{CO}_{3}, \mathrm{Na}_{2} \mathrm{CO}_{3}, \mathrm{NaOH} \\
(0.1 \text { and } 1 \mathrm{~mol} / \mathrm{L}) \text {, and } \mathrm{NaCl} \\
(1 \mathrm{~mol} / \mathrm{L}) \text { was impregnated on } \\
\text { sawdust (the ratio of solution to } \\
\text { biomass was kept at } 16 \mathrm{~mL} / \mathrm{g}) .\end{array}$ & $\begin{array}{c}T=600{ }^{\circ} \mathrm{C} ; \mathrm{N}_{2}, 5000 \mathrm{~mL} / \mathrm{min} ; \\
\text { atmospheric pressure; } \mathrm{HR}: \\
\text { not available; } t=4-5 \mathrm{~min} ; \\
\text { macro-TGA }\end{array}$ & $\begin{array}{l}\mathrm{T}=750-900{ }^{\circ} \mathrm{C} ; \mathrm{CO}_{2} \\
\text { atmospheric pressure; } \\
\text { macro-TGA }\end{array}$ & $\begin{array}{l}\text { Char reactivity increased with the } \\
\text { loading alkali content at low } \\
\text { temperatures and up to a certain } \\
\text { level. When the temperature } \\
\text { increased to } 900^{\circ} \mathrm{C} \text {, no correlation } \\
\text { could be observed. }\end{array}$ \\
\hline Sadhwani et al. [16] & $\begin{array}{l}\text { pine wood chips, } \\
<0.8 \mathrm{~mm}\end{array}$ & $\begin{array}{l}30 \mathrm{~g} \text { of char was added to the } \\
\text { aqueous solution of metal acetate }(\mathrm{K}, \\
\mathrm{Na}, \mathrm{Ca}, \mathrm{Mg}) \text { to get a loading target of } \\
0.1 \mathrm{~g} \text { metal/carbon in the char. } \\
\text { 1. Metal nitrate }(\mathrm{K}, \mathrm{Ca}) \text { was loaded } \\
\text { on acid washed wood by }\end{array}$ & $\begin{array}{c}\mathrm{T}=800{ }^{\circ} \mathrm{C} ; \mathrm{N}_{2}, 7000 \mathrm{~mL} / \mathrm{min} ; \\
\text { atmospheric pressure; } \\
\mathrm{HR}=10{ }^{\circ} \mathrm{C} / \mathrm{min} ; t=60 \mathrm{~min} ; \\
\text { tubular reactor }\end{array}$ & $\begin{array}{c}T=800-945^{\circ} \mathrm{C} ; \mathrm{CO}_{2} \\
1200 \mathrm{~mL} / \mathrm{min} ; \text { atmospheric } \\
\text { pressure; stainless steel } \\
\text { tubular reactor }\end{array}$ & $\begin{array}{c}\text { The reactivity of the chars was in the } \\
\text { order of: K-char }>\text { Ca-char }> \\
\text { Na-char }>\text { Mg-char. }\end{array}$ \\
\hline Perander et al. [17] & $\begin{array}{l}\text { Norwegian spruce, } \\
125-250 \mu \mathrm{m}\end{array}$ & $\begin{array}{c}\text { ion-exchange method (K: } \\
\text { 1200- } 125000 \mathrm{mg} / \mathrm{kg} \text { wood; } \mathrm{Ca}: \\
740-4600 \mathrm{mg} / \mathrm{kg} \text { wood). } \\
\text { 2. } \mathrm{K}_{2} \mathrm{CO}_{3} \text { was impregnated on acid } \\
\text { washed wood } \\
\text { (K: } 3300-17000 \mathrm{mg} / \mathrm{kg} \text { wood). } \\
\text { 3. } \mathrm{CaC}_{2} \mathrm{O}_{4} \cdot \mathrm{H}_{2} \mathrm{O} \text { was added to } \\
\text { acid-washed wood by ion-exchange } \\
\text { method (Ca: } 610-3000 \mathrm{mg} / \mathrm{kg} \text { wood). }\end{array}$ & In situ pyrolysis & $\begin{array}{c}T=850{ }^{\circ} \mathrm{C} ; \mathrm{CO}_{2} ; \text { atmospheric } \\
\text { pressure; TGA }\end{array}$ & $\begin{array}{c}\text { Char gasification rate increased with } \\
\text { the loading content of } \mathrm{Ca} \text { and } \mathrm{K} \text {. } \\
\text { Organically bound } \mathrm{K} \text { and } \mathrm{K}_{2} \mathrm{CO}_{3} \\
\text { showed a similar char reactivity. } \\
\mathrm{CaC}_{2} \mathrm{O}_{4} \text { addition resulted in } \\
\text { lower reactivity. }\end{array}$ \\
\hline
\end{tabular}


Table 2. Cont.

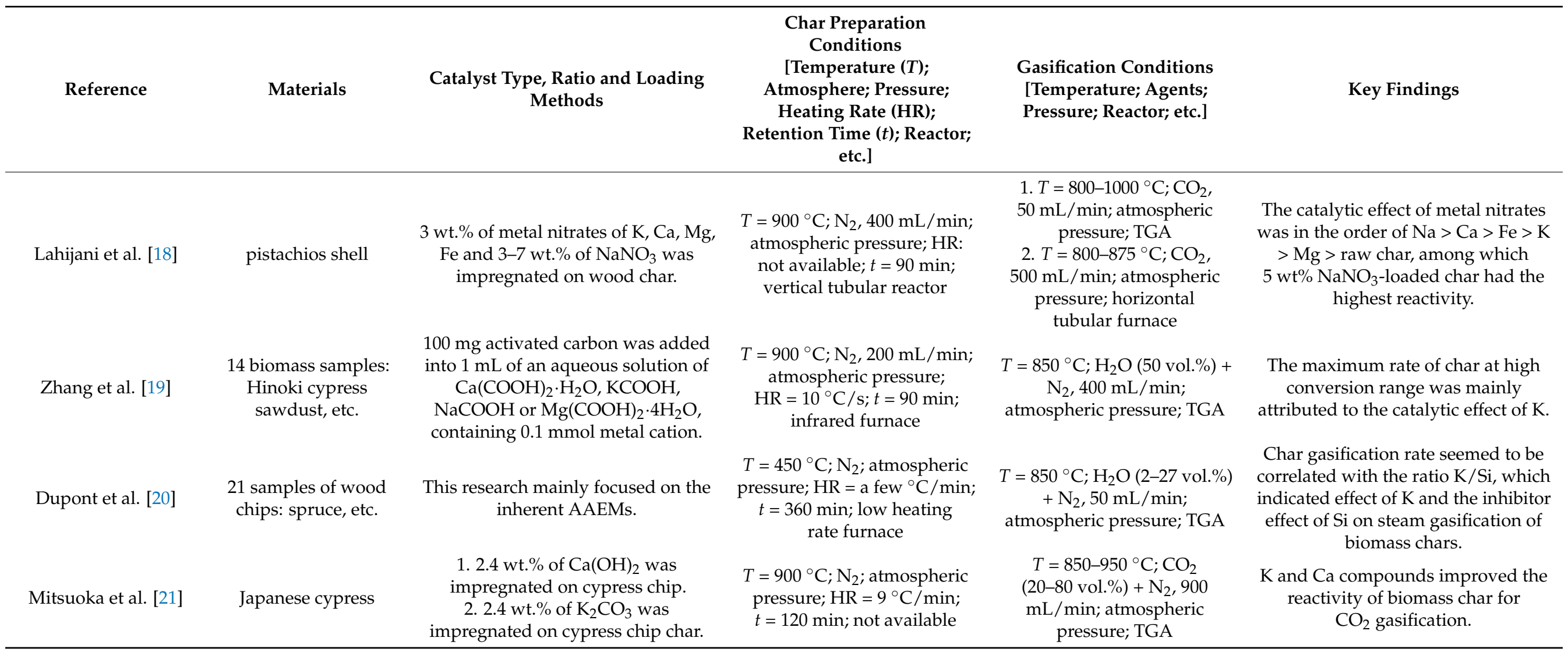




\section{Materials and Methods}

\subsection{Preparation of Char Samples}

Agriculture residues usually have high content of AAEMs [33], and corn stalk (CS) collected from the southeast of Shanxi province was selected as a representative biomass in this study. CS was previously dried in an oven at $105^{\circ} \mathrm{C}$ for $12 \mathrm{~h}$ and then sheared to a particle size of less than $600 \mu \mathrm{m}$. The corn stalk char (CSC) was prepared in a fixed-bed reactor at $900{ }^{\circ} \mathrm{C}$ under $\mathrm{N}_{2}$. Details of the experimental device and procedure have been given elsewhere [24]. CSC was ground to a diameter of less than $100 \mu \mathrm{m}$ and stored in a desiccator for further use. The procedure of preparing water-leached biomass char $\left(\mathrm{H}_{2} \mathrm{O}-\mathrm{CSC}\right.$ ) was as follows: CSC was leached by ultra-pure $\mathrm{H}_{2} \mathrm{O}$ (about $0.25 \mathrm{~g}$ CSC was soaked and stirred by a magnetic stirrer in a round-bottom flask $(500 \mathrm{~mL})$ with $250 \mathrm{~mL}$ ultra-pure $\mathrm{H}_{2} \mathrm{O}$ ) for $6 \mathrm{~h}$ at $60^{\circ} \mathrm{C}$. Then, $\mathrm{H}_{2} \mathrm{O}$-CSC sample was dried in an oven at $105^{\circ} \mathrm{C}$ for $12 \mathrm{~h}$ and stored for further use. The proximate and ultimate analyses of the raw sample and corresponding chars are shown in Table 3.

Table 3. Proximate and ultimate analyses of corn stalk and the corresponding chars.

\begin{tabular}{|c|c|c|c|c|c|c|c|c|c|}
\hline \multirow{2}{*}{ Sample } & \multicolumn{4}{|c|}{ Proximate Analysis $w_{\mathrm{ad}} / \%$} & \multicolumn{5}{|c|}{ Ultimate Analysis $w_{\text {daf }} / \%$} \\
\hline & $\mathbf{M}$ & A & $\mathbf{V}$ & FC & C & $\mathbf{H}$ & O * & $\mathbf{N}$ & $S$ \\
\hline CS & 11.78 & 4.51 & 71.58 & 12.13 & 50.90 & 5.17 & 43.67 & 0.08 & 0.18 \\
\hline CSC & 2.10 & 10.62 & 2.00 & 85.28 & 97.56 & 0.46 & 1.17 & 0.41 & 0.40 \\
\hline $\mathrm{H}_{2} \mathrm{O}-\mathrm{CSC}$ & 2.00 & 6.91 & 2.10 & 88.99 & 97.21 & 0.46 & 1.58 & 0.38 & 0.37 \\
\hline
\end{tabular}

Note: The proximate and ultimate analyses were conducted according to the Chinese National Standard GB/T 212-2008 and GB/T 31391-2015, respectively. ad, air dried basis; daf, dry ash free basis; M, moisture; A, ash; V, volatiles; FC, fixed carbon; *, calculated by difference; $\mathrm{C}$, carbon; $\mathrm{H}$, hydrogen; $\mathrm{O}$, oxygen; $\mathrm{N}$, nitrogen; $\mathrm{S}$, sulfur; $\mathrm{CS}$, corn stalk; $\mathrm{CSC}$, corn stalk char; $\mathrm{H}_{2} \mathrm{O}$-CSC, water-leached corn stalk char.

In addition, the inorganic elements of the char samples were determined by ICPAES (Thermo ICAP 6300, Thermo Fisher Scientific, Waltham, MA, USA) according to the procedure adopted by Jiang et al. [22]. Table 4 lists the contents of the major inorganic elements of the char samples. Compared with some works in the literature [14,19], CSC has a high content of $\mathrm{K}$. After water-leaching treatment, the contents of the inorganic elements all decreased, and the mass fraction of $\mathrm{K}$ and Na dropped dramatically. The primary chemical form of $\mathrm{K}$ and $\mathrm{Na}$ in biomass char is water-soluble [14,34], so the water-leaching treatment caused a massive loss of $\mathrm{K}$ and $\mathrm{Na}$.

Table 4. Contents of the major inorganic elements in char samples.

\begin{tabular}{cccccccc}
\hline \multirow{2}{*}{ Sample } & \multicolumn{7}{c}{ Major Inorganic Elements (mmol/g Dry Sample) } \\
\cline { 2 - 8 } & $\mathbf{A l}$ & $\mathbf{C a}$ & $\mathbf{F e}$ & $\mathbf{K}$ & $\mathbf{M g}$ & $\mathbf{N a}$ & $\mathbf{S i}$ \\
\hline CSC & 0.04 & 0.24 & 0.03 & 1.32 & 0.27 & 0.05 & 0.60 \\
$\mathrm{H}_{2} \mathrm{O}-\mathrm{CSC}$ & 0.03 & 0.18 & 0.02 & 0.25 & 0.20 & 0.01 & 0.54 \\
\hline
\end{tabular}

\subsection{Steam Gasification Tests}

The gasification experiments were performed on a magnetic suspension balance (Rubotherm, 2011-01181-CHN), and steam was used as the gasifying agent. In each test, a $10 \mathrm{mg}$ sample was loaded in a platinum crucible (13 $\mathrm{mm}$ in diameter, $2 \mathrm{~mm}$ in height). Then, the gasification system was sealed and pressurized to the experimental pressure. After that, the sample was heated up in $\mathrm{N}_{2}$ at a constant ramp $\left(20^{\circ} \mathrm{C} / \mathrm{min}\right)$ and flow rate $(200 \mathrm{~mL} / \mathrm{min}$ ) to the desired temperature and maintained for $30 \mathrm{~min}$ until the mass signal and temperature was stable. Then steam was dosed to the system to initiate the reaction. The experiments were conducted in $200 \mathrm{~mL} / \mathrm{min}$ steam $/ \mathrm{N}_{2}$ atmosphere at various total pressures $(0.1-0.7 \mathrm{MPa})$, steam concentrations $(10-70$ vol. $\%)$ and temperatures $\left(725-900{ }^{\circ} \mathrm{C}\right)$. All the experiments were conducted until the mass changes were no longer observed. The experiments were conducted 2-4 times, and the standard deviations of the experiments 
were within $\pm 1 \%$. The carbon conversion $(X)$ and average gasification rate $\left(R_{\mathrm{avg}}\right)$ was calculated by the following equations:

$$
\begin{gathered}
X=\frac{m_{0}-m_{t}}{m_{0}-m_{\infty}}, \\
R_{\mathrm{avg}}=\frac{\sum_{i=1}^{N} \frac{\mathrm{d} X_{i}}{\mathrm{~d} t}}{N}, X_{1}=0.1, X_{N}=0.9,
\end{gathered}
$$

where $m_{0}$ represents the mass of char at the onset of gasification, $m_{t}$ indicates the instantaneous mass of char at time $t$, and $m_{\infty}$ is the final mass of char when the mass changes were no longer observed, in wt.\%, and $N$ is the number of the data adopted. In this paper, $R_{\text {avg }}$ is the average instantaneous reaction rates between $X=0.1$ to 0.9 ; it aims to decrease the error by applying single-point reaction rate. This method is similar to some researchers who adopted the average gasification rate between the conversion of $0-50 \%$ [35], $1-80 \%$ [33] and $60-80 \%$ [36] to compare the reactivities of different biomass char samples.

\subsection{Kinetic Models}

Usually, the gasification behavior can be predicted by two kinds of models: an $n$ thorder one-step model and rate equations based on the stepwise reaction mechanism [37] (Langmuir-Hinshelwood (L-H) model).

The $n$ th-order model can be written as Equation (3), where $k$ is the apparent gasification rate constant, which is related with temperature and the partial pressure of the reagent, and $f(X)$ describes the changes in the physical or chemical properties of the sample as the gasification proceeds. The most-used $n$ th-order models are volumetric model (VM), grain model (GM) and random pore model (RPM) [38]. The forms of these models are listed below, Equations (4)-(6):

$$
\begin{gathered}
\frac{\mathrm{d} X}{\mathrm{~d} t}=k(T, P) f(X), \\
\mathrm{VM}: \frac{\mathrm{d} X}{\mathrm{~d} t}=k_{\mathrm{VM}}(1-X), \\
\mathrm{GM}: \frac{\mathrm{d} X}{\mathrm{~d} t}=k_{\mathrm{GM}}(1-X)^{2 / 3}, \\
\mathrm{RPM}: \frac{\mathrm{d} X}{\mathrm{~d} t}=k_{\mathrm{RPM}}(1-X) \sqrt{1-\psi \ln (1-X),}
\end{gathered}
$$

where $k_{\mathrm{VM}}, k_{\mathrm{GM}}, k_{\mathrm{RPM}}$ denote the respective apparent reaction rate constant and $\psi$ is a pore structural parameter.

In the $n$ th-order model, RPM proposed by Bhatia and Perlmutter (1980) is the most successful model in describing coal char gasification [38-40] and has been used to describe biomass char gasification $[6,18,41]$. However, RPM can only describe the gasification behavior when the maximum gasification rate appears at $X<0.393$. When the gasification rate increases with conversion and shows a maximum at high conversion range $(X>0.393)$, especially for biomass char and catalytic biomass char gasification $[15,17,19,30]$, RPM was no longer adopted. Consequently, a semi-empirical model developed by Zhang et al. [19] was applied to describe such gasification behaviors. The modified random pore model (MRPM) is indicated as below:

$$
\frac{\mathrm{d} X}{\mathrm{~d} t}=k_{\mathrm{MRPM}}(1-X) \sqrt{1-\psi \ln (1-X)}\left(1+(c X)^{p}\right),
$$

where $c$ presents a dimensionless constant and $p$ is a dimensionless power law constant.

When the concentration of the gasifying agent is constant, the apparent reaction rate constant can be expressed by the Arrhenius equation:

$$
k=A \exp (-E a / R T)
$$


where $A, E a$ and $R$ are the pre-exponential factor, activation energy and universal gas constant $(8.314 \mathrm{~J} / \mathrm{mol} \cdot \mathrm{K})$, respectively.

The L-H model is based on adsorption and desorption theories. The expressions of char- $\mathrm{H}_{2} \mathrm{O}$ gasification can be written as Equations (9) and (10):

$$
\begin{gathered}
\mathrm{C}_{f}+\mathrm{H}_{2} \mathrm{O} \stackrel{k_{2}, k_{1}}{\rightarrow} \mathrm{C}(\mathrm{O})+\mathrm{H}_{2}, \\
\mathrm{C}(\mathrm{O}) \stackrel{k_{3}}{\rightarrow} \mathrm{CO}+\mathrm{C}_{f},
\end{gathered}
$$

where $C_{f}$ represents a free active site and $\mathrm{C}(\mathrm{O})$ is an absorbed surface complex, and the total concentration of active sites $C_{t}$ on the sample surface is expressed as:

$$
\left[C_{t}\right]=\left[C_{f}\right]+[\mathrm{C}(\mathrm{O})]
$$

Assuming that the reaction is in a steady state, and the concentration of $\mathrm{C}(\mathrm{O})$ approaches to zero, the gasification rate of char- $\mathrm{H}_{2} \mathrm{O}$ can be written as Equation (12) [42]:

$$
R_{\text {char }-\mathrm{H}_{2} \mathrm{O}}=\frac{k_{1} P_{\mathrm{H}_{2} \mathrm{O}}}{1+K_{2} P_{\mathrm{H}_{2} \mathrm{O}}+K_{3} P_{\mathrm{H}_{2}}},
$$

where $K_{2}=k_{1} / k_{3}, K_{3}=k_{2} / k_{3}, P$ is the partial pressure.

Usually when the system has excess gasifying agent (steam), the partial pressure of $\mathrm{H}_{2}\left(P_{\mathrm{H}_{2}}\right)$ can be neglected $\left(K_{3} P_{\mathrm{H}_{2}}<<K_{2} P_{\mathrm{H}_{2} \mathrm{O}}\right)$; thus, Equation (12) can be simplified to Equation (13) and further transformed to Equation (14), where $k_{1}$ and $k_{2}$ can be calculated by linearizing Equation (8). Then the value of $A$ and $E a$ of the two main steps can be obtained.

$$
\begin{aligned}
& R_{\text {char }-\mathrm{H}_{2} \mathrm{O}}=\frac{k_{1} P_{\mathrm{H}_{2} \mathrm{O}}}{1+K_{2} P_{\mathrm{H}_{2} \mathrm{O}}}, \\
& \frac{1}{R_{\text {char }-\mathrm{H}_{2} \mathrm{O}}}=\frac{1}{k_{1} P_{\mathrm{H}_{2} \mathrm{O}}}+\frac{1}{k_{3}} .
\end{aligned}
$$

\section{Results and Discussion}

\subsection{Effect of Gasification Pressure}

Two types of pressure effects on the gasification rate of CSC have been analyzed, i.e., fixed total pressure with different steam concentrations and fixed steam partial pressures with varying total pressures [43]. Figure 1a shows the effect of steam concentration with a fixed total pressure on the gasification rate of CSC. As can be depicted from the figure, the reaction rate of CSC increases with steam concentration.

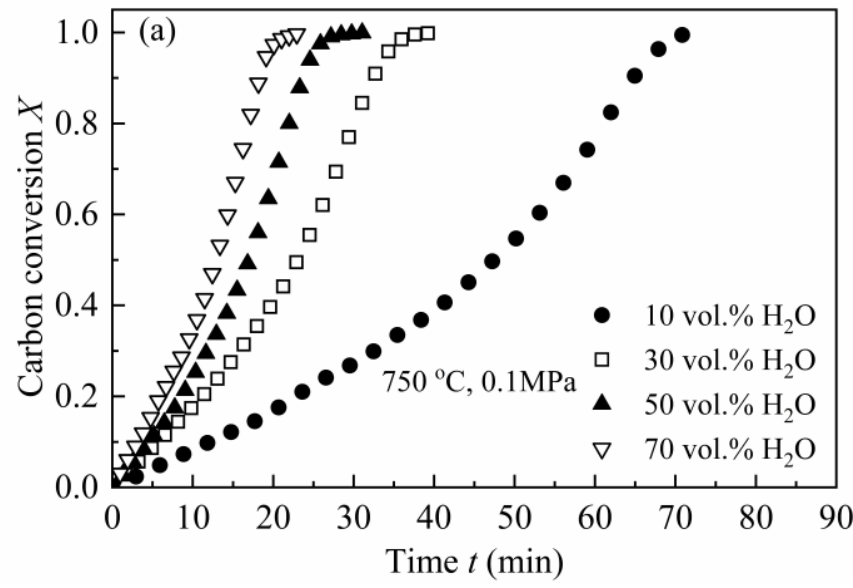

(a)

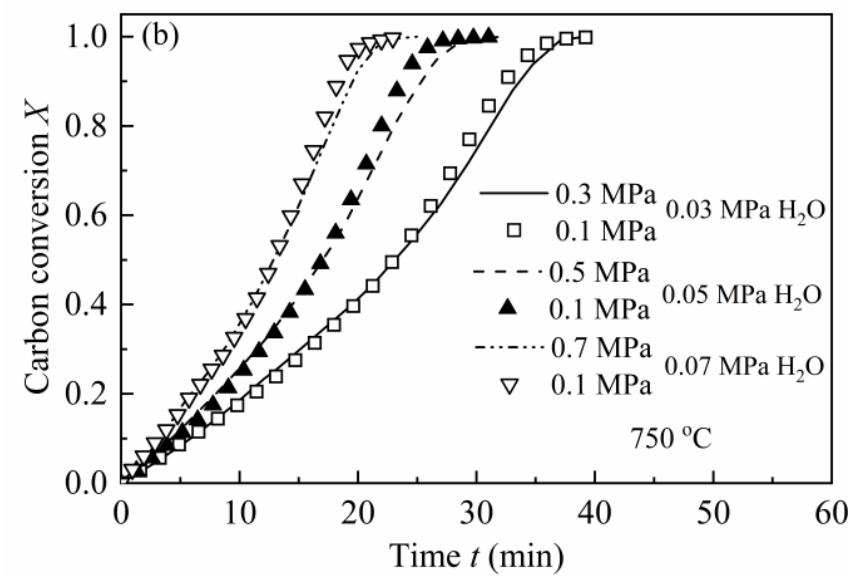

(b)

Figure 1. Pressure effects on the gasification rate of CSC at $750{ }^{\circ} \mathrm{C}$ : (a) different steam concentrations with a constant total pressure of $0.1 \mathrm{MPa}$; (b) different total pressures with fixed steam partial pressures $(0.03,0.05$ and $0.07 \mathrm{MPa})$, respectively. 
Figure $1 \mathrm{~b}$ illustrates the results of fixed steam partial pressures with different total pressures on the gasification rate of CSC. As can be seen, there are no clear differences when the steam partial pressure is fixed but with different total pressures. This is consistent with the results of some researchers, i.e., that total pressure has no influence on the intrinsic gasification rate of chars, except for the diffusion effect of the reactant $[28,44,45]$. Thus, this research mainly focused on the gasification of CSC under at 0.1 MPa with different steam concentrations $(10,30,50$ and 70 vol. $\%)$.

\subsection{Effect of Gasification Temperature}

The effect of gasification temperature on the reaction rate of CSC was tested at 725-825 ${ }^{\circ} \mathrm{C}$ and $0.1 \mathrm{MPa}$ with steam concentrations of 10-70 vol.\%. Results were processed according to the method mentioned in Section 2.2 (the reaction rate was obtained by averaging the instantaneous reaction rates between $X=0.1$ to 0.9 ). The gasification rates at different steam concentrations and temperatures were listed in Table 5, and the Arrhenius plots were shown in Figure 2. As seen in Table 5, at low steam concentrations (10 and 30 vol.\%), the gasification rate grows very fast with temperature, i.e., the rate at $825{ }^{\circ} \mathrm{C}$ is nearly eight times at $725^{\circ} \mathrm{C}(83.86 / 10.57=7.93,130 / 17.78=7.31)$. At high steam concentrations (50 and 70 vol.\%), the growth of gasification rate slows down, for the reaction rate of $825^{\circ} \mathrm{C}$ is about six times that of $725^{\circ} \mathrm{C}(160 / 24.92=6.42,200 / 31.42=6.37)$. This phenomenon can be explained by the effect of temperature on the reaction order, in which the reaction order with respect to steam partial pressure decreases with the increase in gasification temperature (seen in Section 3.3).

Table 5. Gasification rates and activation energies of CSC at $0.1 \mathrm{MPa}$ with various steam concentrations and temperatures.

\begin{tabular}{|c|c|c|c|c|}
\hline $\begin{array}{c}\text { Steam Concentration } \\
\text { (vol.\%) }\end{array}$ & $T\left({ }^{\circ} \mathrm{C}\right)$ & $R_{\text {avg }}\left(10^{-3} \cdot \min ^{-1}\right)$ & $R^{2}$ & $\begin{array}{c}E a \\
(\mathrm{~kJ} / \mathrm{mol})\end{array}$ \\
\hline \multirow{5}{*}{10} & 725 & 10.57 & \multirow{5}{*}{0.9982} & \multirow{5}{*}{186.21} \\
\hline & 750 & 18.66 & & \\
\hline & 775 & 32.58 & & \\
\hline & 800 & 48.94 & & \\
\hline & 825 & 83.86 & & \\
\hline \multirow{5}{*}{30} & 725 & 17.78 & \multirow{5}{*}{0.9967} & \multirow{5}{*}{179.63} \\
\hline & 750 & 33.50 & & \\
\hline & 775 & 50.17 & & \\
\hline & 800 & 86.23 & & \\
\hline & 825 & 130.00 & & \\
\hline \multirow{5}{*}{50} & 725 & 24.92 & \multirow{5}{*}{0.9942} & \multirow{5}{*}{165.38} \\
\hline & 750 & 46.55 & & \\
\hline & 775 & 65.00 & & \\
\hline & 800 & 105.15 & & \\
\hline & 825 & 160.00 & & \\
\hline \multirow{5}{*}{70} & 725 & 31.42 & \multirow{5}{*}{0.9947} & \multirow{5}{*}{167.39} \\
\hline & 750 & 53.80 & & \\
\hline & 775 & 75.00 & & \\
\hline & 800 & 131.50 & & \\
\hline & 825 & 200.00 & & \\
\hline
\end{tabular}

The Arrhenius plot was used to evaluate the char reactivities at different temperatures. The value of $E a$ was obtained by linearizing Equation (3) (where $k(T, P)$ was substituted by Equation (8)) without considering the specific form of $f(X)$. This method, discussed by Vyazovkin et al. [46,47], was called the model-free method and is usually applied to data for non-isothermal and isothermal decompositions of solids. The use of the model-free method is recommended as a trustworthy way of obtaining reliable kinetic parameters. The value of $E a$ obtained in this way is closer to the true value. The corresponding plots of various steam concentrations were developed to determine Ea. At low temperatures, the reaction is under chemical control zone. As the temperature increases, diffusion control 
becomes dominant [48-50]. The straight line in Figure 2 and the high regression coefficients $\left(R^{2}>0.99\right)$ listed in Table 5 indicate the gasification reactions are all under chemical control zone. The values of $E a(167-187 \mathrm{~kJ} / \mathrm{mol})$ are within the ranges of biomass char steam gasification summarized in the literature [1]. In Table 5, it is noticeable that $E a$ decreases when the steam concentration increases; however, when the steam concentration reaches 50 vol.\%, Ea no longer decreases and remains stable. It can be explained as when the concentration of the reagent grows, the effective collision between the reactant atom and the carbon atom increases, so the gasification reaction happens more easily, and Ea becomes lower. When the steam concentration is high enough, the adsorption of steam on the char surface intends to be saturated [51]; thus, Ea grows slowly when the steam ratio increases further.

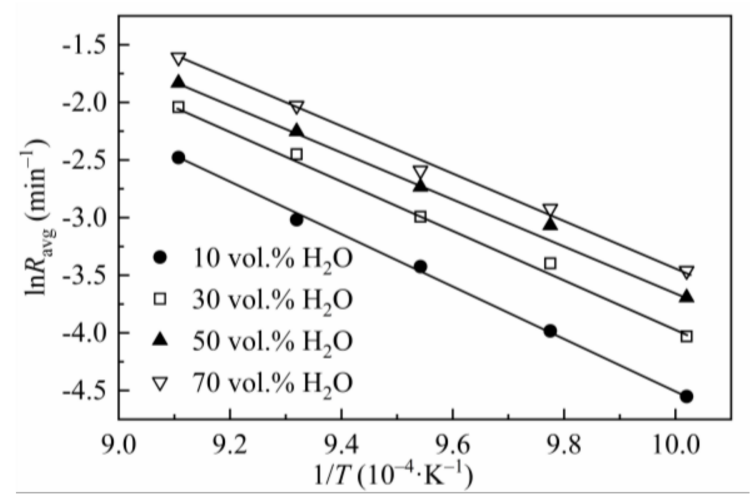

Figure 2. Arrhenius plots of $\ln R_{\text {avg }}$ versus $1 / T$ for CSC.

\subsection{Reaction Order}

The effect of steam partial pressure on CSC gasification rate can be described by the reaction order with respect to steam partial pressure. Equation (2) can be expressed by the following:

$$
R_{\text {avg }}=b P_{\mathrm{H}_{2} \mathrm{O}}{ }^{n},
$$

where $b$ is a constant, $P_{\mathrm{H}_{2} \mathrm{O}}$ is the partial pressure of steam, and $n$ is the reaction order with respect to steam partial pressure, which can be calculated by linearizing Equation (15).

As obtained from Figure 3, the reaction order of char steam gasification was listed in Table 6 and in the range of 0.43-0.55. Marquez-Montesinos [52] et al. reported the values of reaction order for grapefruit char gasification were 0.5-0.6. Lopez et al. [53] found the reaction order with respect to steam partial pressure was 0.34 for pinewood sawdust. Fermoso et al. [38] found that the reaction order with respect to steam partial pressure for chestnut char and olive stones char was 0.40 and 0.52 , respectively. The reaction order obtained here differs from other studies, which may be caused by different biomass resources. However, the value of $n$ is in the range listed in the literature [1].

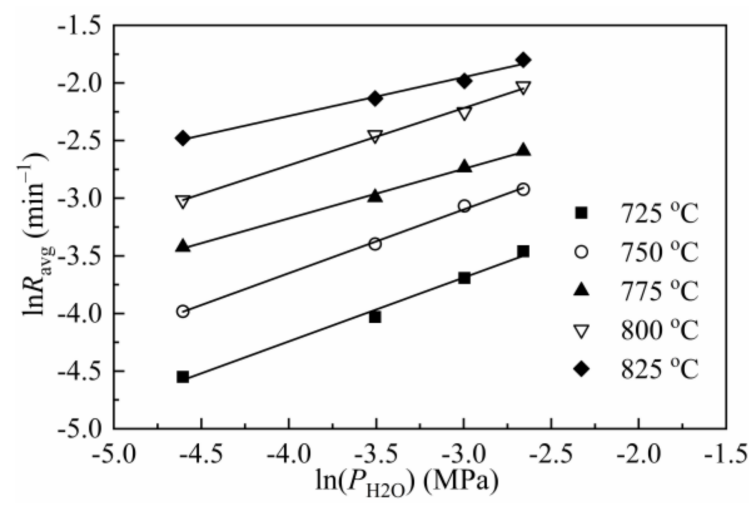

Figure 3. Reactivity of CSC as a function of steam partial pressure. 
Table 6. Reaction order and regression coefficients of CSC at $0.1 \mathrm{MPa}$ with steam concentrations of 10-70 vol.\%.

\begin{tabular}{ccc}
\hline Partial Pressure & \multicolumn{2}{c}{$\mathbf{0 . 1} \mathbf{M P a}(\mathbf{1 0 , 3 0 , 5 0 , 7 0 ~ v o l . \% )}$} \\
\hline $\boldsymbol{T}\left({ }^{\circ} \mathbf{C}\right)$ & $\boldsymbol{n}$ & $\boldsymbol{R}^{\mathbf{2}}$ \\
725 & 0.5539 & 0.9911 \\
750 & 0.5525 & 0.9980 \\
775 & 0.4299 & 0.9971 \\
800 & 0.4969 & 0.9961 \\
825 & 0.4332 & 0.9875 \\
Average & 0.4933 & - \\
\hline
\end{tabular}

\subsection{Kinetics}

\subsubsection{The Application of MRPM to Describe Biomass Char Gasification Behaviors}

As mentioned in Section 2.3, the $n$ th-order model is usually applied to evaluate the gasification kinetics of carbonaceous materials. However, according to the expression of VM, GM and RPM (Equations (4)-(6)), the gasification rates predicted by VM and GM are all decreased with carbon conversion, and the maximum rate of RPM is less than 0.393 [54]. It is obviously not appropriate to use these models to describe the gasification behaviors of biomass chars of which the gasification rate increases with conversion and the maximum value appears at conversion above 0.393 .

From the shape of the plot of $\mathrm{d} X / \mathrm{d} t-X$ (Figure 4 ), it can be easily found that the maximum reaction rates are all at high conversion range, which has a remarkable difference with the plot of coal char gasification [26-29]. As mentioned by some researchers $[19,23,24,55]$, the maximum gasification rate of biomass char appearing at high conversion was caused by the high content of AAEMs within char and the effect of enrichment of the AAEMs caused by carbon consuming. Therefore, MRPM proposed by Zhang et al. [19] was adopted to evaluate such biomass char gasification.

The gasification rate versus carbon conversion profiles at various temperatures and steam concentrations were depicted in Figure 4. The results of the application of MRPM were also presented in Figure 4. As can be noted from the figure, the carbon conversions corresponding to the maximum gasification rates are all around $X=0.8$, which can be explained by the above-mentioned reasons. It can also be seen from Figure 4 that MRPM is well applied to fit the gasification results, and all the regression coefficients of the model are above 0.97 (which was listed in Table 7). It is shown in Table 7 that the value of $\psi$ has no regular pattern with temperature or steam concentration, and the average value of $\psi, c$ and $p$ is around 6.8, 1.8 and 3.0, respectively, which are in the range of the literatures $[7,15,19]$. According to Zhang et al. [19], who developed MRPM, $\psi$ was obtained by adopting RPM to fit the experimental data as best as it can be; however, this way of getting $\psi$ was not theoretically adequate. In this paper, $\psi$ was gained by optimizing the experimental data with taking $k_{\mathrm{MRPM}}, \psi, c, p$ as unknown parameters, and this method had been widely verified $[7,15,24,27]$. 

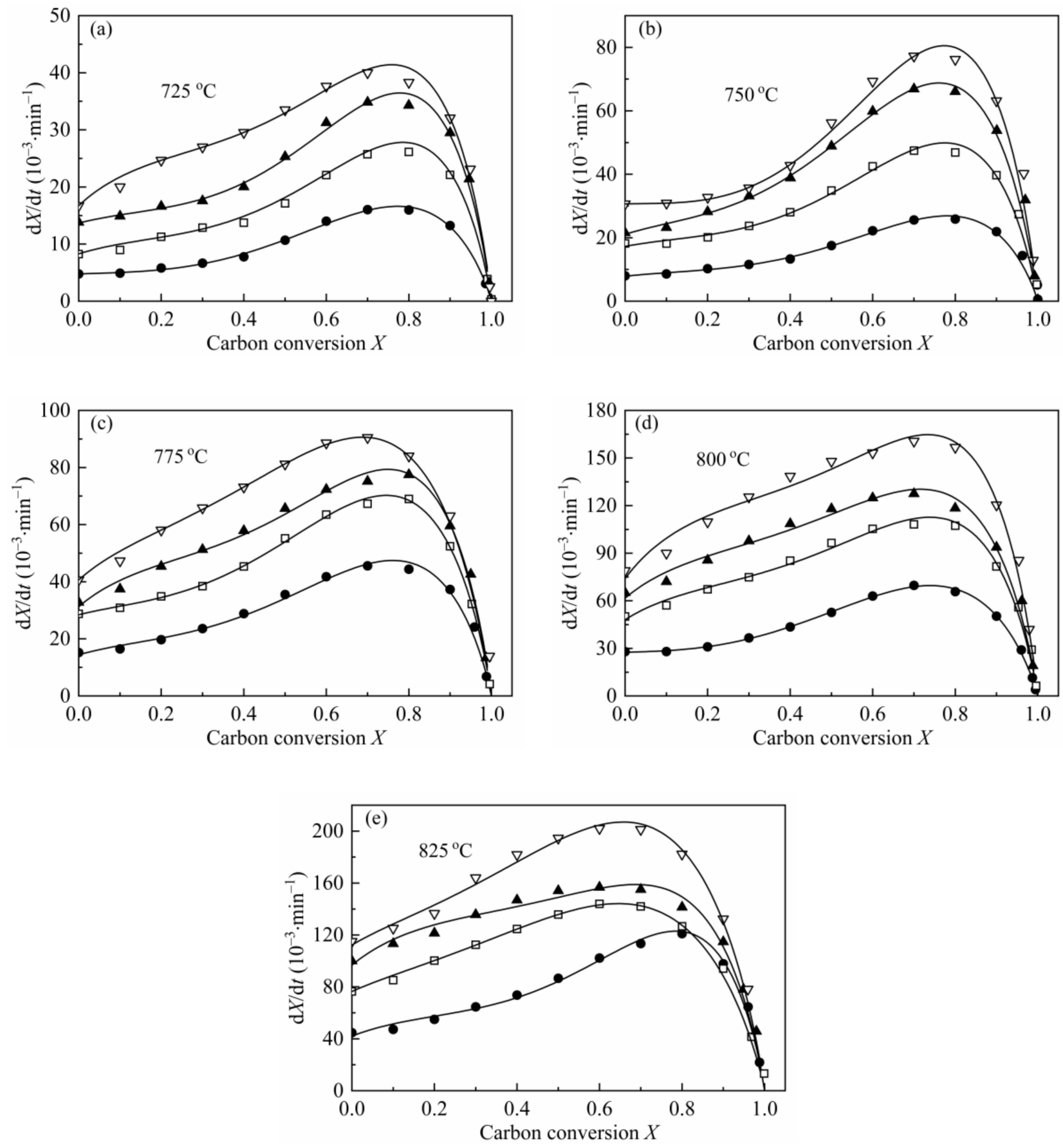

Figure 4. Application of MRPM to describe the gasification behaviors of CSC at $0.1 \mathrm{MPa}, 725-825^{\circ} \mathrm{C}(\mathbf{a}-\mathbf{e})$, with different steam concentrations. •:10 vol. $\%$; $\square: 30$ vol. \%; $\mathbf{4}: 50$ vol. $\%$; $\nabla: 70$ vol. $\%$; solid line: MRPM results. 
Table 7. Kinetic parameters and regression coefficients of MRPM for CSC at $0.1 \mathrm{MPa}$ with different temperatures and steam concentrations.

\begin{tabular}{|c|c|c|c|c|c|c|c|c|}
\hline $\begin{array}{c}\text { Steam } \\
\text { Concentration } \\
(\text { vol.\%) }\end{array}$ & $T\left({ }^{\circ} \mathrm{C}\right)$ & $k_{\mathrm{MRPM}}\left(10^{-3} \min ^{-1}\right)$ & $\psi$ & $c$ & $p$ & $R^{2}$ & $\frac{E a}{(\mathrm{~kJ} / \mathrm{mol})}$ & $A\left(\min ^{-1}\right)$ \\
\hline \multirow[t]{5}{*}{ 年 } & 725 & 4.80 & 3.22 & 2.30 & 2.92 & 0.9951 & \multirow{5}{*}{204.26} & \multirow{5}{*}{$2.25 \times 10^{8}$} \\
\hline & 750 & 7.90 & 5.45 & 2.01 & 3.12 & 0.9883 & & \\
\hline & 775 & 14.40 & 7.79 & 1.91 & 2.90 & 0.9845 & & \\
\hline & 800 & 27.50 & 2.62 & 2.21 & 2.58 & 0.9979 & & \\
\hline & 825 & 42.10 & 7.97 & 2.01 & 3.12 & 0.9875 & & \\
\hline \multirow{5}{*}{30} & 725 & 8.30 & 7.39 & 1.85 & 3.32 & 0.9941 & \multirow{5}{*}{199.42} & \multirow{5}{*}{$2.43 \times 10^{8}$} \\
\hline & 750 & 17.30 & 4.75 & 1.93 & 3.12 & 0.9827 & & \\
\hline & 775 & 28.50 & 4.52 & 1.90 & 2.77 & 0.9982 & & \\
\hline & 800 & 48.10 & 9.00 & 1.54 & 3.10 & 0.9871 & & \\
\hline & 825 & 76.50 & 5.79 & 1.56 & 2.13 & 0.9947 & & \\
\hline \multirow{5}{*}{50} & 725 & 13.68 & 4.68 & 1.84 & 3.26 & 0.9915 & \multirow{5}{*}{187.38} & \multirow{5}{*}{$8.01 \times 10^{7}$} \\
\hline & 750 & 21.06 & 5.95 & 2.03 & 2.83 & 0.9883 & & \\
\hline & 775 & 31.26 & 10.05 & 1.55 & 3.21 & 0.9899 & & \\
\hline & 800 & 61.66 & 9.23 & 1.44 & 3.06 & 0.9779 & & \\
\hline & 825 & 105.30 & 7.46 & 1.30 & 3.33 & 0.9806 & & \\
\hline \multirow{5}{*}{70} & 725 & 16.73 & 10.25 & 1.51 & 3.42 & 0.9892 & \multirow{5}{*}{170.87} & \multirow{5}{*}{$1.49 \times 10^{7}$} \\
\hline & 750 & 30.67 & 5.21 & 2.12 & 3.08 & 0.9859 & & \\
\hline & 775 & 40.65 & 8.39 & 1.55 & 2.49 & 0.9901 & & \\
\hline & 800 & 74.04 & 11.59 & 1.39 & 3.44 & 0.9778 & & \\
\hline & 825 & 112.30 & 5.37 & 1.57 & 2.24 & 0.9839 & & \\
\hline
\end{tabular}

The activation energy Ea listed in Table 7 was obtained by linearizing Equation (8), and $k_{\text {MRPM }}$ was obtained from MRPM. Figure 5 is the Arrhenius plot of $\ln k_{\text {MRPM }}$ versus $1 / T$ for CSC gasified at $0.1 \mathrm{MPa}$ with different steam concentrations.

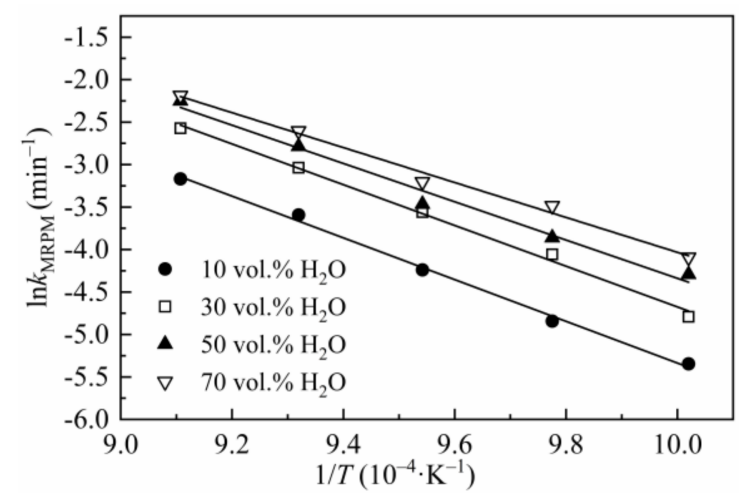

Figure 5. Arrhenius plots of $\ln k_{\mathrm{MRPM}}$ versus $1 / \mathrm{T}$ for CSC.

Compared with Table 5, the value of $E a$ in Table 7 varied remarkably. This discrepancy is mainly caused by two different methods of data processing. In Section 3.2, the value of $E a$ in Table 5 was obtained by linearized Equation (3) (where $k(T, P)$ is substituted by Equation (8)) without considering the specific form of $f(X)$, and the same method had been adopted by Lahijani et al. [48]. In Equation (3), $\mathrm{d} X / \mathrm{d} t$ was obtained by averaging the instantaneous reaction rates between $X=0.1$ to 0.9 , which aims to reduce the uncertainties by applying single point reaction rate. However, the value of $E a$ in Table 7 was obtained from $k_{\text {MRMP }}$, which was derived from MRPM by optimizing the experimental data. In Equation (6), $k_{\text {MRPM }}$ is the value of $\mathrm{d} X / \mathrm{d} t$, when $X=0$. In summary, $E a$ in Table 5 was obtained according to the meaning value of $\mathrm{d} X / \mathrm{d} t$ at different temperatures and steam concentrations, whereas $E a$ in Table 7 was gained by a single point $\mathrm{d} X / \mathrm{d} t(X=0)$ of MRPM at different temperatures and steam concentrations. 


\subsubsection{The Effect of Water Leaching on Biomass Char Gasification Behaviors}

Many researchers reported the catalytic effect of AAEMs on biomass char gasification $[14-18,20,21,25,56]$. In most cases, the catalytic effect of AAEMs was investigated by loading AAEMs on a low-ash-content biomass char (e.g., pine wood char, nut shell char). Results showed that AAEMs have a remarkable improvement on the gasification rates of biomass chars, and some researchers found the impregnation of AAEMs made the maximum gasification rate of biomass char shift to higher conversion [15,17], which was consistent with the phenomenon that appeared in this paper. Compared with some works [14,19], CSC adopted in this research has a high content of AAEMs (especially $\mathrm{K})$, which may cause the special gasification behaviors. However, there is little research concerning with the effect of indigenous AAEMs on the gasification behaviors of biomass char. Feng et al. [14] studied the effect of chemical speciation of AAEMs on the steam gasification of a biomass char and found the speciation of $\mathrm{K}, \mathrm{Na}$ in biomass char was mainly water-soluble, while $\mathrm{Ca}$ and $\mathrm{Mg}$ are mainly in insoluble form, and $\mathrm{H}_{2} \mathrm{O}$-soluble AAEMs play an important role in biomass char reactivity.

In order to verify the catalytic effect of indigenous AAEMs on the gasification behaviors of biomass char, a water-leached biomass char $\left(\mathrm{H}_{2} \mathrm{O}-\mathrm{CSC}\right)$ was prepared. According to Table 4 , about $80 \mathrm{wt} . \%$ of $\mathrm{K}$ and $\mathrm{Na}$ and $25 \mathrm{wt} . \%$ of $\mathrm{Ca}$ and $\mathrm{Mg}$ was removed by waterleaching treatment. According to Jiang et al. [57], the water-leaching method rarely changed the pore structure and surface area of the original biomass char, and the carbonization structure was almost not influenced by the water-leaching treatment [56]. The gasification of $\mathrm{H}_{2} \mathrm{O}-\mathrm{CSC}$ was compared with CSC at $800-900{ }^{\circ} \mathrm{C}, 0.1 \mathrm{MPa}$ with a steam concentration of 10 vol.\%. Figure 6 shows the comparison between the gasification reactivity of CSC and $\mathrm{H}_{2} \mathrm{O}-\mathrm{CSC}$ at different temperatures. As depicted from the figure, after water leaching, the reaction rate of $\mathrm{H}_{2} \mathrm{O}-\mathrm{CSC}$ decreased significantly. A comparison of reaction time (the time for carbon conversion reached $X=0.9$ ) and average reaction rate (reaction rate between $X=0.1-0.9$ ) was shown in Table 8. As seen in Table 8, compared with CSC, the time for $\mathrm{H}_{2} \mathrm{O}-\mathrm{CSC}$ to reach $\mathrm{X}=0.9$ is shortened, and the average reaction rate of CSC is about $4.3(48.94 / 11.30), 3.3(115.38 / 34.49)$ and $2.5(228.70 / 89.88)$ times the average reaction rate of $\mathrm{H}_{2} \mathrm{O}-\mathrm{CSC}$ at 800,850 and $900{ }^{\circ} \mathrm{C}$, respectively. Since about $80 \mathrm{wt} . \%$ of $\mathrm{K}$ and Na were removed by water leaching, and water soluble AAEMs play a crucial role in biomass char reactivity [14], it can be concluded that AAEMs (especially $\mathrm{K}$ and $\mathrm{Na}$ ) have an obviously promoting effect on CSC gasification rate.

From Figure 6, it can be observed that the shape of $d X / d t-X$ for $\mathrm{H}_{2} \mathrm{O}-\mathrm{CSC}$ changes a lot compared with CSC, and the reaction rate no longer grows with carbon conversion; however, it decreases gradually (except for $850^{\circ} \mathrm{C}$, there is an increase before $X=0.2$ ). This is an obvious distinction compared with the gasification behavior of CSC, for the gasification rate of CSC increases with carbon conversion to a maximum (around $X=0.7-0.8$ ), then decreases. The MRPM proposed by Zhang et al. [19] is more suitable for biomass char that has a maximum reaction rate at the high conversion range $(X>0.393)$. Since the gasification behaviors of $\mathrm{H}_{2} \mathrm{O}-\mathrm{CSC}$ changed, MRPM is no longer appropriate to predict its gasification behavior. Other $n$ th-order models of VM, GM and RPM were applied to evaluate the experimental results of $\mathrm{H}_{2} \mathrm{O}-\mathrm{CSC}$. The method adopted here can be found in references [23,58]. The integral forms of VM, GM and RPM (Equations (16)-(18)) were used to get the reaction rate constant $k$, and then $A$ and $E a$ were obtained by linearizing Equation (8).

$$
\begin{gathered}
-\ln (1-X)=k_{\mathrm{VM}} \cdot t \\
3\left[1-(1-X)^{1 / 3}\right]=k_{\mathrm{GM}} \cdot t \\
(2 / \psi)\left[(1-\psi \ln (1-X))^{1 / 2}-1\right]=k_{\mathrm{RPM}} \cdot t .
\end{gathered}
$$

In order to avoid any uncertainties at high conversions where quite little char is left $(X>0.9$, there is a sudden decrease in reaction rate), $X=0-0.9$ was chosen for simulation. 
Figure 7 shows the linearized models of VM, GM and RPM and coefficients for $\mathrm{H}_{2} \mathrm{O}-\mathrm{CSC}$. Moreover, the reaction rate constant $k$ was obtained from the slope (seen in Table 9).
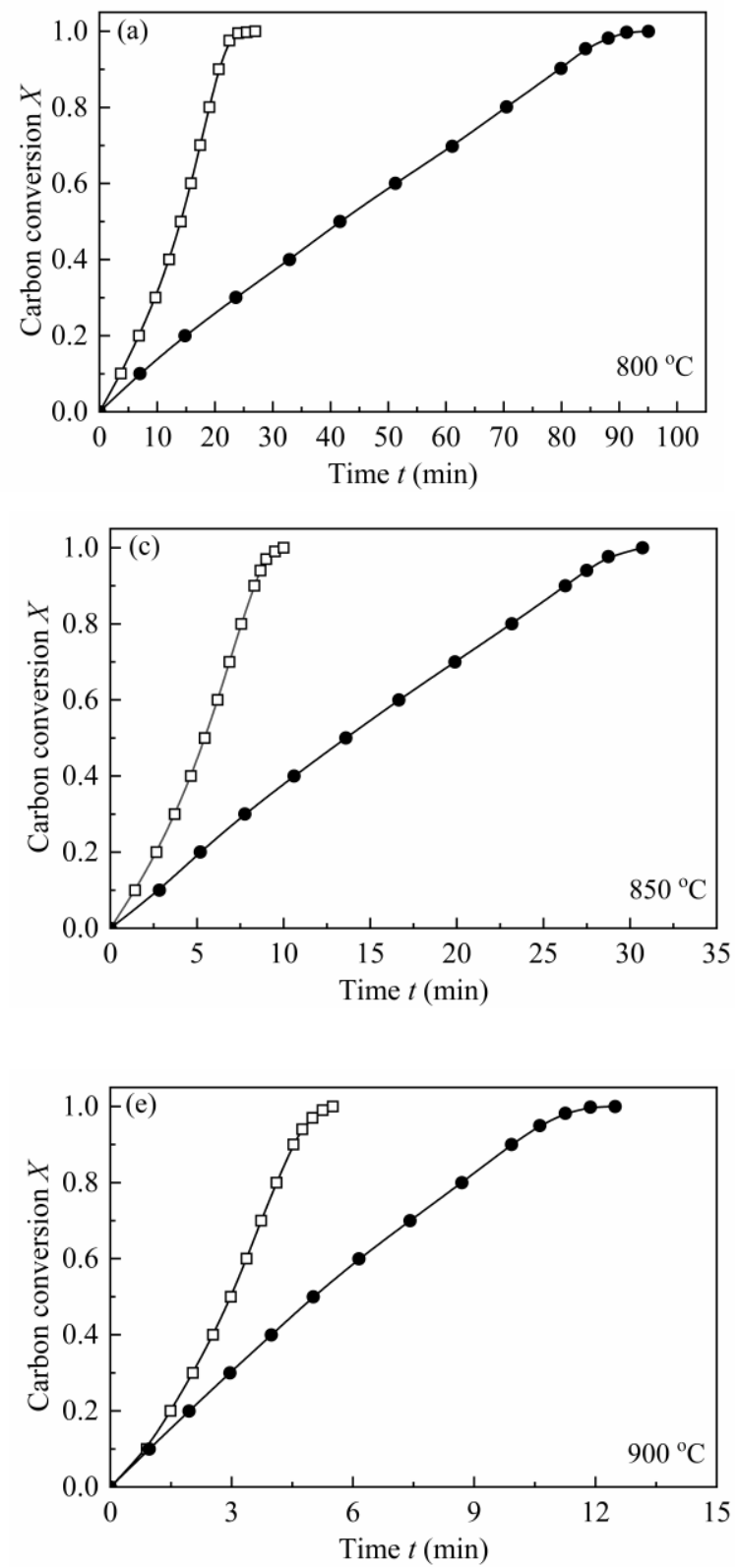
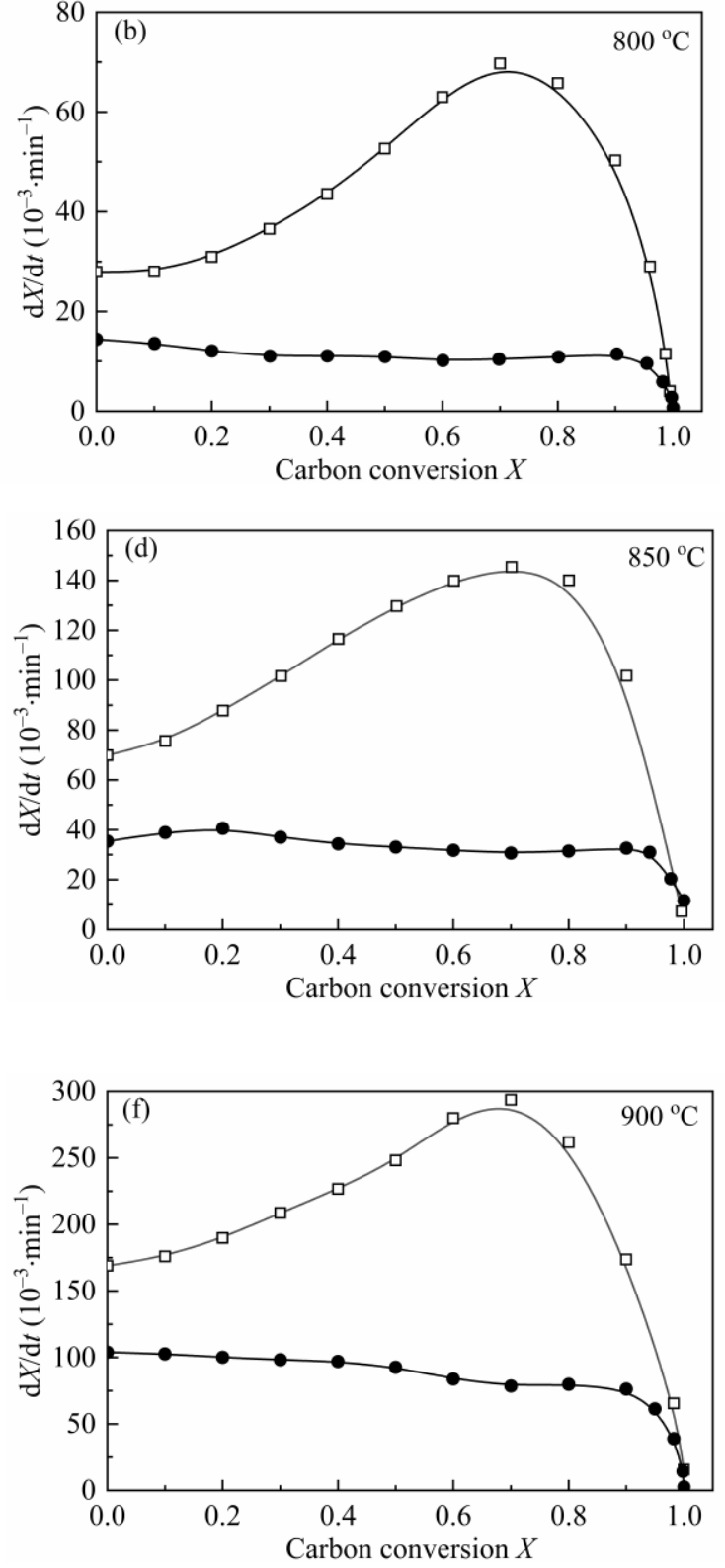

Figure 6. Reactivity comparisons of CSC and $\mathrm{H}_{2} \mathrm{O}-\mathrm{CSC}$ at $0.1 \mathrm{MPa}$ with 10 vol. $\% \mathrm{H}_{2} \mathrm{O} .-\square-$ : CSC; — —- $\mathrm{H}_{2} \mathrm{O}-\mathrm{CSC}$.

Table 8. Reactivity comparisons of CSC and $\mathrm{H}_{2} \mathrm{O}-\mathrm{CSC}$ at $0.1 \mathrm{MPa}$ with 10 vol. $\% \mathrm{H}_{2} \mathrm{O}$.

\begin{tabular}{ccccccc}
\hline \multirow{2}{*}{ Sample } & \multicolumn{3}{c}{ Time of $\boldsymbol{X}=\mathbf{0 . 9}$ (min) } & \multicolumn{3}{c}{$\boldsymbol{R}_{\text {avg }}\left(\mathbf{1 0}^{-\mathbf{3}} \cdot \mathbf{m i n}^{-\mathbf{1}}\right)$} \\
\cline { 2 - 7 } & $\mathbf{8 0 0}{ }^{\circ} \mathbf{C}$ & $\mathbf{8 5 0}{ }^{\circ} \mathbf{C}$ & $\mathbf{9 0 0}{ }^{\circ} \mathbf{C}$ & $\mathbf{8 0 0}^{\circ} \mathbf{C}$ & $\mathbf{8 5 0}^{\circ} \mathbf{C}$ & $\mathbf{9 0 0}^{\circ} \mathbf{C}$ \\
\hline CSC & 20.65 & 8.31 & 4.53 & 48.94 & 115.38 & 228.70 \\
$\mathrm{H}_{2} \mathrm{O}-\mathrm{CSC}$ & 79.90 & 26.26 & 9.92 & 11.30 & 34.49 & 89.88 \\
\hline
\end{tabular}



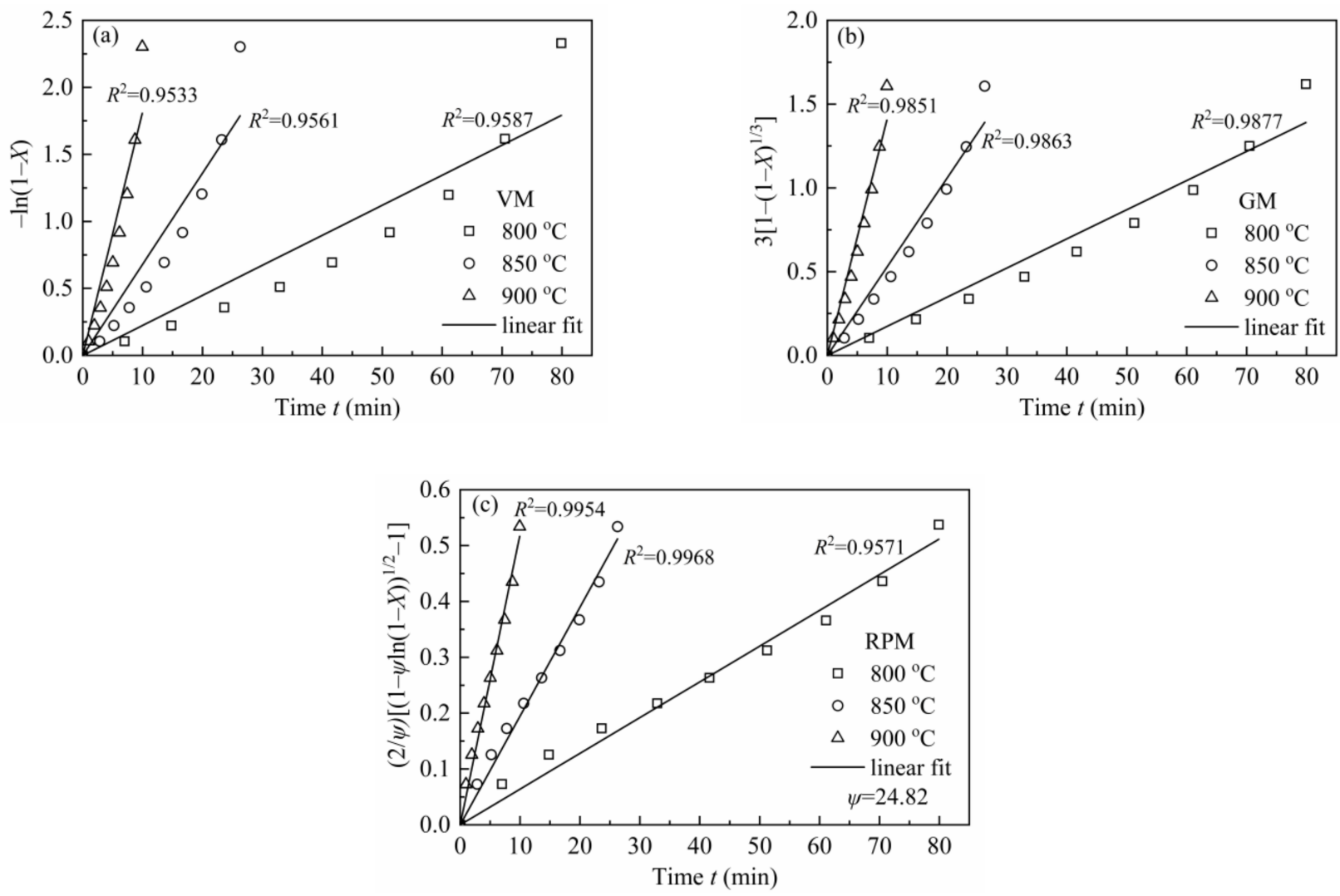

Figure 7. VM, GM and RPM linearized models for $\mathrm{H}_{2} \mathrm{O}-\mathrm{CSC}$ at $0.1 \mathrm{MPa}$ with 10 vol. $\% \mathrm{H}_{2} \mathrm{O}$.

Table 9. Kinetic parameters of VM, GM and RPM by fitting kinetic data of $\mathrm{H}_{2} \mathrm{O}-\mathrm{CSC}$.

\begin{tabular}{|c|c|c|c|c|c|c|c|c|c|}
\hline \multirow{2}{*}{ Parameters } & \multicolumn{9}{|c|}{ Reaction Model } \\
\hline & \multicolumn{3}{|c|}{ VM } & \multicolumn{3}{|c|}{ GM } & \multicolumn{3}{|c|}{ RPM } \\
\hline$T\left({ }^{\circ} \mathrm{C}\right)$ & 800 & 850 & 900 & 800 & 850 & 900 & 800 & 850 & 900 \\
\hline$k\left(10^{-2} \cdot \min ^{-1}\right)$ & 2.24 & 6.81 & 18.2 & 1.74 & 5.30 & 14.15 & 0.64 & 1.95 & 5.21 \\
\hline$E a(\mathrm{~kJ} / \mathrm{mol})$ & & 219.33 & & & 219.43 & & & 219.54 & \\
\hline$A\left(\min ^{-1}\right)$ & & $1.07 \times 10^{9}$ & & & $8.40 \times 10^{8}$ & & & $3.13 \times 10^{8}$ & \\
\hline$\psi$ & & - & & & - & & & 24.82 & \\
\hline$R^{2}$ & & 0.9999 & & & 0.9999 & & & 0.9999 & \\
\hline
\end{tabular}

In RPM, $\psi$ was calculated by the method developed by Everson et al. [59], and a reduced time $t_{X} / t_{0.9}$ was introduced to Equation (18) to calculate $\psi$ :

$$
\frac{t}{t_{0.9}}=\frac{\sqrt{1-\psi \ln (1-X)}-1}{\sqrt{1-\psi \ln (1-0.9)}-1}
$$

where $t_{X}$ is the time for carbon conversion reach $X$ and $t_{0.9}$ is the time for $X=0.9$.

According to Equation (19), the value of $\psi$ was calculated as 24.82 , which was shown in Figure 8. Compared with the value of $\psi$ (varied from 2 to 12) for CSC in MRPM, it is larger. A high value of $\psi$ indicates a high porosity of the char sample, and more reactions will occur at the internal pores of the char [60]. Other researchers also obtained a high value of $\psi$ by using RPM to describe biomass char gasification, i.e., Wang et al. [23] found the value of $\psi$ for maize cob char, wheat straw char and pine sawdust was $128.24,88.54$ and 149.37, respectively; Lin et al. [6] observed a value of $\psi$ of 15 and 450 for Wood 800-5 and Miscanthus 800-15, respectively. 


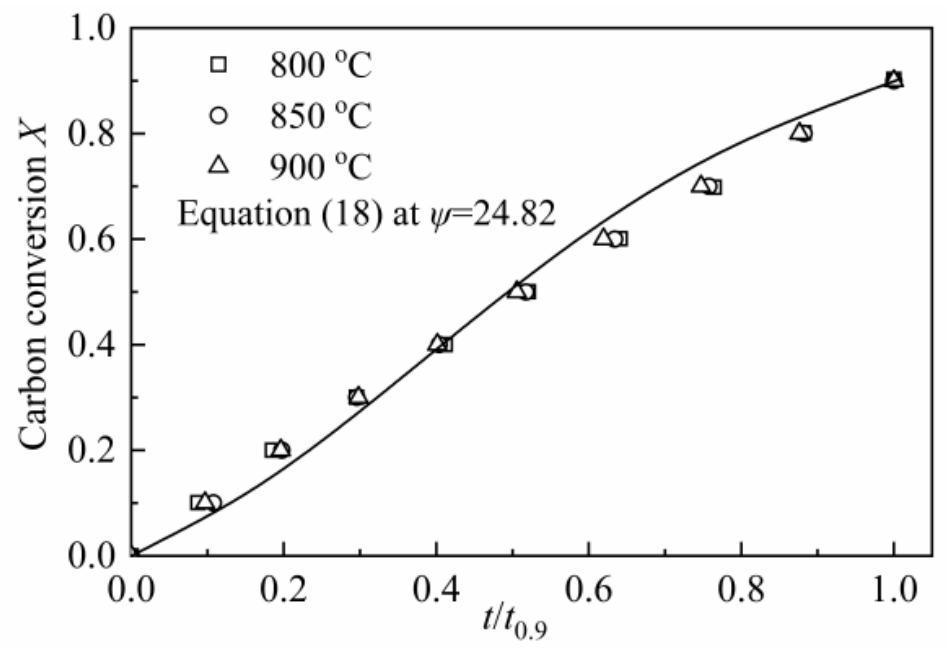

Figure 8. Determination of the structural parameter $\psi$ for CSC.

Figure 9 is the Arrhenius plots of $\mathrm{H}_{2} \mathrm{O}-\mathrm{CSC}$ by using reaction constants calculated from VM, GM and RPM. The values of $E a$ and $A$ obtained by adopting different models are listed in Table 9. Compared with Table 5 or Table 7, the value of $E a$ for $\mathrm{H}_{2} \mathrm{O}-\mathrm{CSC}$ is higher than CSC, which can be attributed to the loss of catalytic effect of AAEMs after water-leaching process.

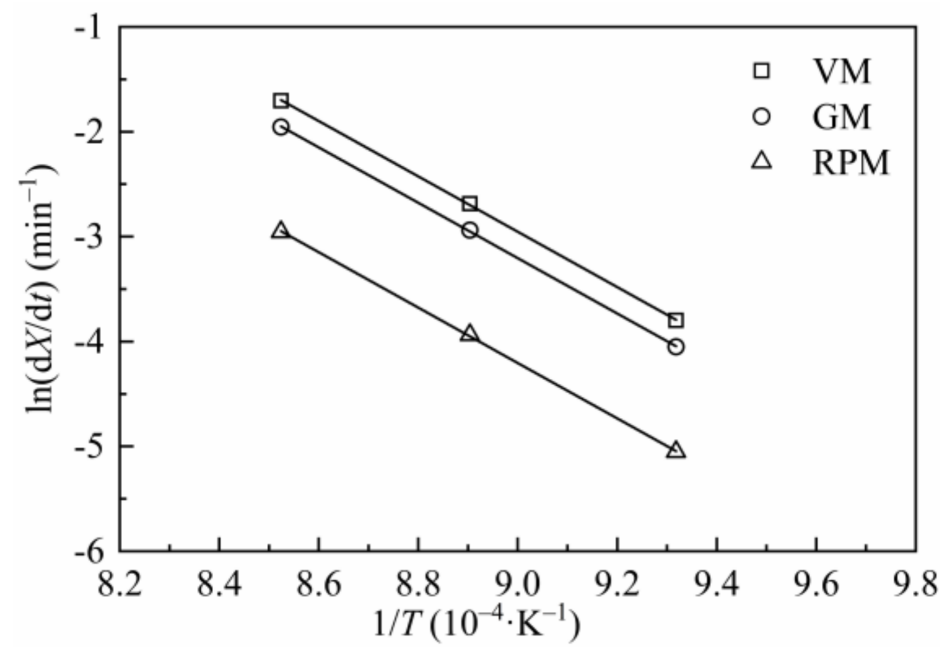

Figure 9. Arrhenius plots for VM, GM and RPM of $\mathrm{H}_{2} \mathrm{O}-\mathrm{CSC}$.

In order to validate each model, the experimental data was compared with the calculated values at different temperatures, which was shown in Figure 10. In accordance with Figure 10, the better the linear relation in Figure 7, the higher goodness of fit between the experimental and model calculation results in Figure 10 will be. In conclusion, MRPM is no longer appropriate for predicting the gasification behaviors of $\mathrm{H}_{2} \mathrm{O}-\mathrm{CSC}$; instead, RPM gives a better fitting result for $\mathrm{H}_{2} \mathrm{O}-\mathrm{CSC}$, followed by GM and VM. It can be considered that the loss of AAEM (especially $\mathrm{K}$ in this paper) by water leaching leads to the decrease in reaction rate and an obvious change of the shape of $\mathrm{d} X / \mathrm{dt}-X$, thus making MRPM inappropriate to evaluate the gasification behaviors of $\mathrm{H}_{2} \mathrm{O}-\mathrm{CSC}$. However, a deep understanding about the influence of AAEMs on biomass char gasification modeling needs to be explored in future work. 

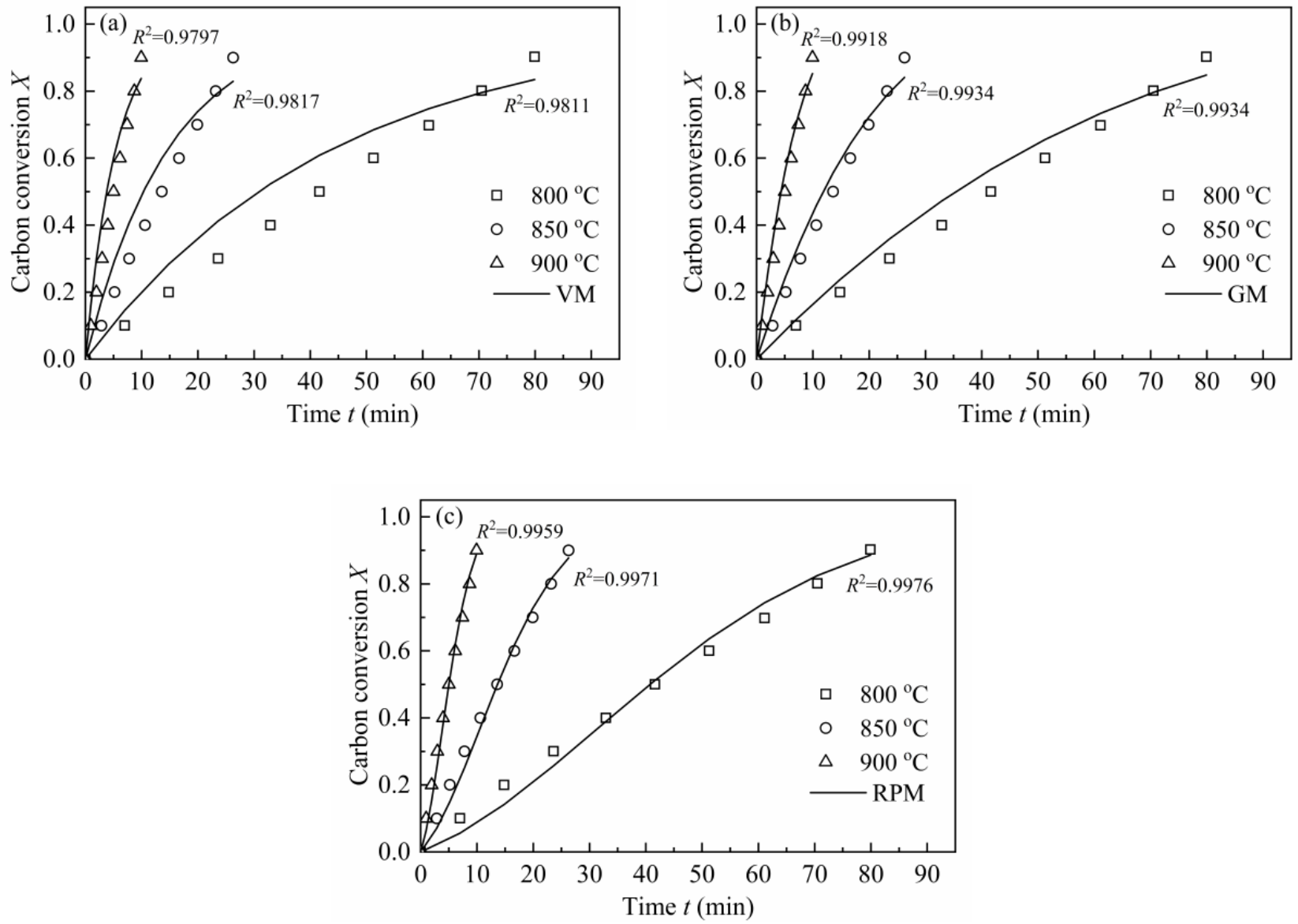

Figure 10. Comparison between experimental data and calculated values of $\mathrm{H}_{2} \mathrm{O}-\mathrm{CSC}$ by VM, GM, RPM at $0.1 \mathrm{MPa}$ with 10 vol. $\% \mathrm{H}_{2} \mathrm{O}$.

\subsubsection{The Application of the L-H Model to Interpret Biomass Char Gasification}

The L-H model has been applied by many researchers to describe the gasification behaviors of char and gave excellent predictions of the gasification results [51,61]. Figure 11 shows $1 / R$ versus $1 / P$ and $\ln \left(k_{\mathrm{i}}\right)$ versus $1 / T$ for CSC at different temperatures and a total pressure of $0.1 \mathrm{MPa}$, and the goodness of fit of the experimental results versus calculated values is also presented in the figure. Figure 11a,b indicates a good linear correlation between $1 / R$ and $1 / P, \ln \left(k_{\mathrm{i}}\right)$ and $1 / T$, respectively. Figure $11 \mathrm{c}$ shows that most of the calculated data lies near the line of $y=x$, which indicates that the $\mathrm{L}-\mathrm{H}$ model can be well applied in the prediction of gasification behavior of CSC. Table 10 lists the kinetic parameters and regression coefficients of the L-H model. The values of $E_{a 1}$ and $E_{a 3}$ are $202.08 \mathrm{~kJ} / \mathrm{mol}$ and $157.84 \mathrm{~kJ} / \mathrm{mol}$, respectively. The L-H model can predict the gasification behavior at different temperatures and gasification agent partial pressures without considering the structure characters of gasification materials and can be well applied in the simulation of gasification process. 

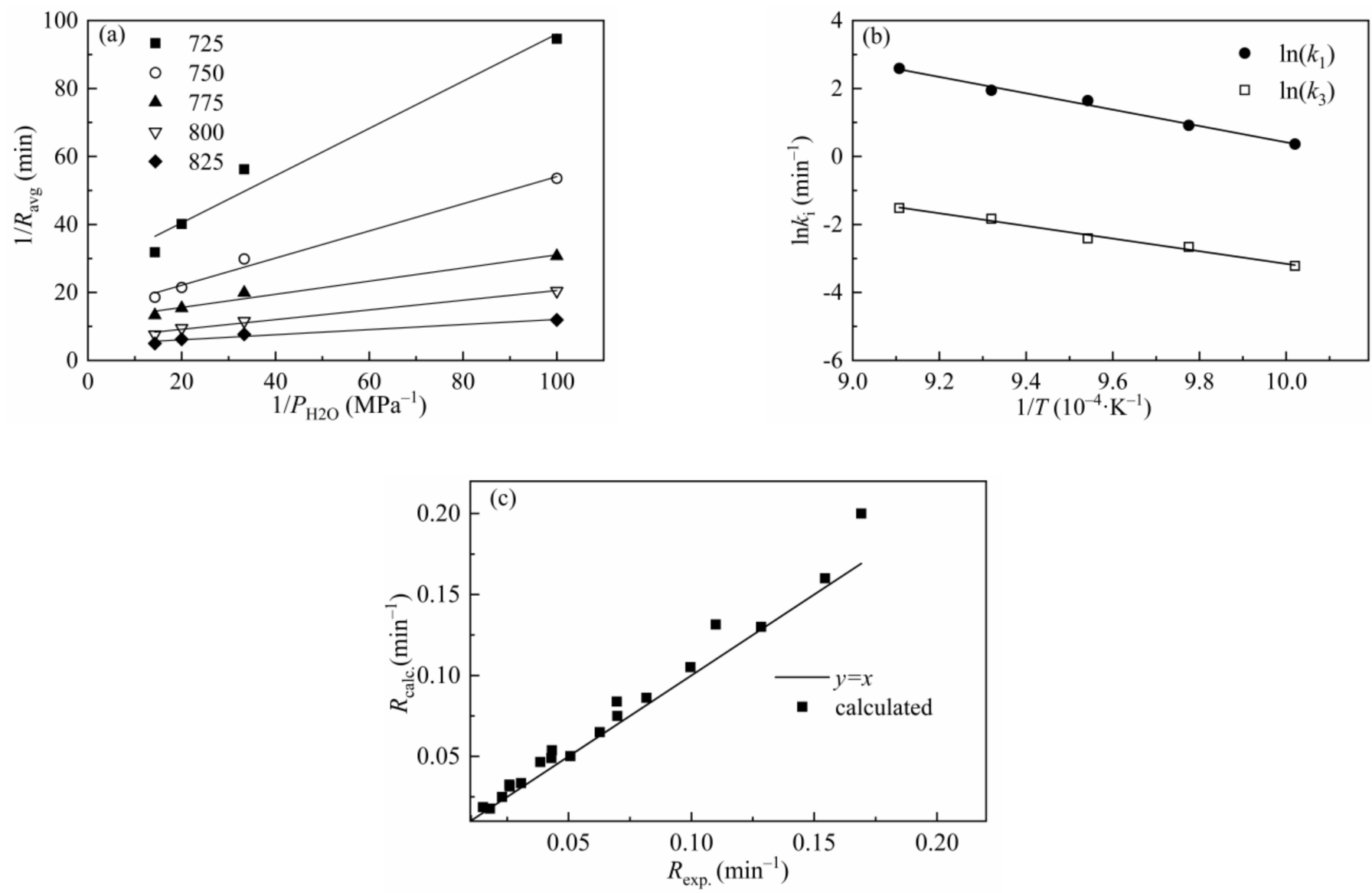

Figure 11. Relationship between (a) $1 / R_{\mathrm{avg}}$ and $1 / P_{\mathrm{H} 2 \mathrm{O}}$ and $(\mathbf{b}) \ln \left(k_{\mathrm{i}}\right)$ and $1 / T$ for CSC; (c) comparison of the experimental results with calculated values of the $\mathrm{L}-\mathrm{H}$ model.

Table 10. Kinetic parameters and regression coefficients of L-H model for CSC.

\begin{tabular}{|c|c|c|c|c|c|c|c|c|c|}
\hline Parameter & $k_{1}$ & $k_{3}$ & $R^{2}$ & $E a_{1}$ & $A_{1}$ & $R^{2}$ & $E a_{3}$ & $A_{3}$ & $R^{2}$ \\
\hline$T\left({ }^{\circ} \mathrm{C}\right)$ & $\left(\min ^{-1} \cdot \mathrm{MPa}^{-1}\right)$ & $\left(\min ^{-1}\right)$ & & $(\mathrm{kJ} / \mathrm{mol})$ & $\left(\min ^{-1} \cdot \mathrm{MPa}^{-1}\right)$ & & $(\mathrm{kJ} / \mathrm{mol})$ & $\left(\min ^{-1}\right)$ & \\
\hline 725 & 1.44 & 0.04 & 0.9716 & & & & & & \\
\hline 750 & 2.50 & 0.07 & 0.9894 & & & & & & \\
\hline 775 & 5.17 & 0.09 & 0.9744 & 202.08 & $4.17 \times 10^{10}$ & 0.9904 & 157.84 & $7.17 \times 10^{6}$ & 0.9795 \\
\hline 800 & 7.01 & 0.16 & 0.9899 & & & & & & \\
\hline 825 & 13.33 & 0.22 & 0.9687 & & & & & & \\
\hline
\end{tabular}

\section{Conclusions}

The steam gasification behaviors of corn stalk char and water-leached corn stalk char were analyzed in a magnetic suspension balance. Results showed that there were no clear differences of total pressure effect on CSC gasification rate with a fixed steam partial pressure. The influence of temperature on the reaction rate is more obvious at high steam concentrations. The reaction order of CSC steam gasification with respect to steam partial pressure is in the range of 0.43 0.55. The MRPM and L-H model fitted the gasification results of CSC well. Due to the loss of AAEMs caused by water-leaching treatment, the gasification rate of $\mathrm{H}_{2} \mathrm{O}-\mathrm{CSC}$ dropped dramatically, and the value of $\mathrm{Ea}$ became higher. Moreover, MRPM can no longer be applied to describe the gasification behaviors of $\mathrm{H}_{2} \mathrm{O}$ CSC; instead, RPM gives a better fitting result for $\mathrm{H}_{2} \mathrm{O}-\mathrm{CSC}$, followed by GM and VM. All the evidence indicates that AAEMs within biomass char have an important influence on its gasification behaviors. 
Author Contributions: Conceptualization, Z.Q. and L.D.; methodology, S.Z.; formal analysis, S.Z., Y.R., B.B. and Z.L.; writing-original draft preparation, S.Z.; writing-review and editing, L.D.; supervision, L.D. All authors have read and agreed to the published version of the manuscript.

Funding: This research was funded by National Natural Science Foundation of China (21908176 and 21878243).

Acknowledgments: This work has been supported by the National Natural Science Foundation of China (21908176 and 21878243).

Conflicts of Interest: The authors declare no conflict of interest.

\section{References}

1. Di Blasi, C. Combustion and gasification rates of lignocellulosic chars. Prog. Energy Combust. Sci. 2009, 35, 121-140. [CrossRef]

2. Widjaya, E.R.; Chen, G.; Bowtell, L.; Hills, C. Gasification of non-woody biomass: A literature review. Renew. Sustain. Energy Rev. 2018, 89, 184-193. [CrossRef]

3. Zhang, Y.; Geng, P.; Zheng, Y. Exploration and practice to improve the kinetic analysis of char- $\mathrm{CO}_{2}$ gasification via thermogravimetric analysis. Chem. Eng. J. 2019, 359, 298-304. [CrossRef]

4. Safarian, S.; Unnpórsson, R.; Richter, C. A review of biomass gasification modelling. Renew. Sustain. Energy Rev. 2019, 110, 378-391. [CrossRef]

5. Gao, X.; Zhang, Y.; Li, B.; Zhao, Y.; Jiang, B. Determination of the intrinsic reactivities for carbon dioxide gasification of rice husk chars through using random pore model. Bioresour. Technol. 2016, 218, 1073-1081. [CrossRef]

6. Lin, L.; Strand, M. Investigation of the intrinsic $\mathrm{CO}_{2}$ gasification kinetics of biomass char at medium to high temperatures. Appl. Energy 2013, 109, 220-228. [CrossRef]

7. Chew, J.J.; Soh, M.; Sunarso, J.; Yong, S.-T.; Doshi, V.; Bhattacharya, S. Isothermal kinetic study of $\mathrm{CO}_{2}$ gasification of torrefied oil palm biomass. Biomass Bioenergy 2020, 134, 105487. [CrossRef]

8. Strandberg, A.; Holmgren, P.; Wagner, D.R.; Molinder, R.; Wiinikka, H.; Umeki, K.; Broström, M. Effects of Pyrolysis Conditions and Ash Formation on Gasification Rates of Biomass Char. Energy Fuels 2017, 31, 6507-6514. [CrossRef]

9. Cetin, E.; Moghtaderi, B.; Gupta, R.; Wall, T.F. Biomass gasification kinetics: Influences of pressure and char structure. Combust. Sci. Technol. 2005, 177, 765-791. [CrossRef]

10. Okumura, Y.; Hanaoka, T.; Sakanishi, K. Effect of pyrolysis conditions on gasification reactivity of woody biomass-derived char. Proc. Combust. Inst. 2009, 32, 2013-2020. [CrossRef]

11. Septien, S.; Escudero Sanz, F.J.; Salvador, S.; Valin, S. The effect of pyrolysis heating rate on the steam gasification reactivity of char from woodchips. Energy 2018, 142, 68-78. [CrossRef]

12. Dahou, T.; Defoort, F.; Thiéry, S.; Grateau, M.; Campargue, M.; Bennici, S.; Jeguirim, M.; Dupont, C. The Influence of Char Preparation and Biomass Type on Char Steam Gasification Kinetics. Energies 2018, 11, 2126. [CrossRef]

13. Xiao, R.; Yang, W. Kinetics characteristics of straw semi-char gasification with carbon dioxide. Bioresour. Technol. 2016, 207, 180-187. [CrossRef] [PubMed]

14. Feng, D.; Zhao, Y.; Zhang, Y.; Sun, S.; Gao, J. Steam Gasification of Sawdust Biochar Influenced by Chemical Speciation of Alkali and Alkaline Earth Metallic Species. Energies 2018, 11, 205. [CrossRef]

15. Kirtania, K.; Axelsson, J.; Matsakas, L.; Christakopoulos, P.; Umeki, K.; Furusjö, E. Kinetic study of catalytic gasification of wood char impregnated with different alkali salts. Energy 2017, 118, 1055-1065. [CrossRef]

16. Sadhwani, N.; Adhikari, S.; Eden, M.R.; Wang, Z.; Baker, R. Southern pines char gasification with $\mathrm{CO}_{2}-\mathrm{Kinetics}$ and effect of alkali and alkaline earth metals. Fuel Process. Technol. 2016, 150, 64-70. [CrossRef]

17. Perander, M.; DeMartini, N.; Brink, A.; Kramb, J.; Karlström, O.; Hemming, J.; Moilanen, A.; Konttinen, J.; Hupa, M. Catalytic effect of $\mathrm{Ca}$ and $\mathrm{K}$ on $\mathrm{CO}_{2}$ gasification of spruce wood char. Fuel 2015, 150, 464-472. [CrossRef]

18. Lahijani, P.; Zainal, Z.A.; Mohamed, A.R.; Mohammadi, $\mathrm{M} . \mathrm{CO}_{2}$ gasification reactivity of biomass char: Catalytic influence of alkali, alkaline earth and transition metal salts. Bioresour. Technol. 2013, 144, 288-295. [CrossRef]

19. Zhang, Y.; Ashizawa, M.; Kajitani, S.; Miura, K. Proposal of a semi-empirical kinetic model to reconcile with gasification reactivity profiles of biomass chars. Fuel 2008, 87, 475-481. [CrossRef]

20. Dupont, C.; Nocquet, T.; Da Costa, J.A., Jr.; Verne-Tournon, C. Kinetic modelling of steam gasification of various woody biomass chars: Influence of inorganic elements. Bioresour. Technol. 2011, 102, 9743-9748. [CrossRef]

21. Mitsuoka, K.; Hayashi, S.; Amano, H.; Kayahara, K.; Sasaoaka, E.; Uddin, M.A. Gasification of woody biomass char with $\mathrm{CO}_{2}$ : The catalytic effects of $\mathrm{K}$ and $\mathrm{Ca}$ species on char gasification reactivity. Fuel Process. Technol. 2011, 92, 26-31. [CrossRef]

22. Long, J.; Song, H.; Jun, X.; Sheng, S.; Lun-shi, S.; Kai, X.; Yao, Y. Release characteristics of alkali and alkaline earth metallic species during biomass pyrolysis and steam gasification process. Bioresour. Technol. 2012, 116, 278-284. [CrossRef]

23. Wang, G.; Zhang, J.; Shao, J.; Liu, Z.; Wang, H.; Li, X.; Zhang, P.; Geng, W.; Zhang, G. Experimental and modeling studies on $\mathrm{CO}_{2}$ gasification of biomass chars. Energy 2016, 114, 143-154. [CrossRef]

24. Ding, L.; Zhang, Y.; Wang, Z.; Huang, J.; Fang, Y. Interaction and its induced inhibiting or synergistic effects during co-gasification of coal char and biomass char. Bioresour. Technol. 2014, 173, 11-20. [CrossRef] [PubMed] 
25. Dahou, T.; Defoort, F.; Jeguirim, M.; Dupont, C. Towards understanding the role of K during biomass steam gasification. Fuel 2020, 282, 118806. [CrossRef]

26. Wang, Y.; Bell, D.A. Reaction kinetics of Powder River Basin coal gasification in carbon dioxide using a modified drop tube reactor. Fuel 2015, 140, 616-625. [CrossRef]

27. Jing, X.; Wang, Z.; Yu, Z.; Zhang, Q.; Li, C.; Fang, Y. Experimental and Kinetic Investigations of $\mathrm{CO}_{2}$ Gasification of Fine Chars Separated from a Pilot-Scale Fluidized-Bed Gasifier. Energy Fuels 2013, 27, 2422-2430. [CrossRef]

28. Kajitani, S.; Hara, S.; Matsuda, H. Gasification rate analysis of coal char with a pressurized drop tube furnace. Fuel 2002, 81, 539-546. [CrossRef]

29. Peng, F.F.; Lee, I.C.; Yang, R.Y.K. Reactivities of in situ and ex situ coal chars during gasification in steam at $1000-1400{ }^{\circ} \mathrm{C}$. Fuel Process. Technol. 1995, 41, 233-251. [CrossRef]

30. Arnold, R.A.; Habibi, R.; Kopyscinski, J.; Hill, J.M. Interaction of Potassium and Calcium in the Catalytic Gasification of Biosolids and Switchgrass. Energy Fuels 2017, 31, 6240-6247. [CrossRef]

31. Zhang, R.; Wang, Q.H.; Luo, Z.Y.; Fang, M.X.; Cen, K.F. Competition and Inhibition Effects during Coal Char Gasification in the Mixture of $\mathrm{H}_{2} \mathrm{O}$ and $\mathrm{CO}_{2}$. Energy Fuels 2013, 27, 5107-5115. [CrossRef]

32. Roberts, D.G.; Harris, D.J. A Kinetic Analysis of Coal Char Gasification Reactions at High Pressures. Energy Fuels 2006, 20, 2314-2320. [CrossRef]

33. Dupont, C.; Jacob, S.; Marrakchy, K.O.; Hognon, C.; Grateau, M.; Labalette, F.; Da Silva Perez, D. How inorganic elements of biomass influence char steam gasification kinetics. Energy 2016, 109, 430-435. [CrossRef]

34. Song, Y.-C.; Li, Q.-T.; Li, F.-Z.; Wang, L.-S.; Hu, C.-C.; Feng, J.; Li, W.-Y. Pathway of biomass-potassium migration in co-gasification of coal and biomass. Fuel 2019, 239, 365-372. [CrossRef]

35. Chen, G.; Yu, Q.; Sjöström, K. Reactivity of char from pyrolysis of birch wood. J. Anal. Appl. Pyrolysis 1997, 40-41, 491-499. [CrossRef]

36. DeGroot, W.F.; Shafizadeh, F. Kinetics of gasification of Douglas Fir and Cottonwood chars by carbon dioxide. Fuel 1984, 63, 210-216. [CrossRef]

37. Fermoso, J.; Stevanov, C.; Moghtaderi, B.; Arias, B.; Pevida, C.; Plaza, M.G.; Rubiera, F.; Pis, J.J. High-pressure gasification reactivity of biomass chars produced at different temperatures. J. Anal. Appl. Pyrolysis 2009, 85, 287-293. [CrossRef]

38. Fermoso, J.; Arias, B.; Pevida, C.; Plaza, M.G.; Rubiera, F.; Pis, J.J. Kinetic models comparison for steam gasification of different nature fuel chars. J. Therm. Anal. Calorim. 2008, 91, 779-786. [CrossRef]

39. Tanner, J.; Bhattacharya, S. Kinetics of $\mathrm{CO}_{2}$ and steam gasification of Victorian brown coal chars. Chem. Eng. J. 2016, 285, 331-340. [CrossRef]

40. Fermoso, J.; Gil, M.V.; Garcia, S.; Pevida, C.; Pis, J.J.; Rubiera, F. Kinetic Parameters and Reactivity for the Steam Gasification of Coal Chars Obtained under Different Pyrolysis Temperatures and Pressures. Energy Fuels 2011, 25, 3574-3580. [CrossRef]

41. Seo, D.K.; Lee, S.K.; Kang, M.W.; Hwang, J.; Yu, T.-U. Gasification reactivity of biomass chars with $\mathrm{CO}_{2}$. Biomass Bioenergy 2010, 34, 1946-1953. [CrossRef]

42. Wang, Y.; Bell, D.A. Competition between $\mathrm{H}_{2} \mathrm{O}$ and $\mathrm{CO}_{2}$ during the gasification of Powder River Basin coal. Fuel 2017, 187, 94-102. [CrossRef]

43. Wall, T.F.; Liu, G.-s.; Wu, H.-w.; Roberts, D.G.; Benfell, K.E.; Gupta, S.; Lucas, J.A.; Harris, D.J. The effects of pressure on coal reactions during pulverised coal combustion and gasification. Prog. Energy Combust. Sci. 2002, 28, 405-433. [CrossRef]

44. Roberts, D.G.; Harris, D.J.; Wall, T.F. Total pressure effects on chemical reaction rates of chars with $\mathrm{O}_{2}, \mathrm{CO}_{2}$ and $\mathrm{H}_{2} \mathrm{O}$. Fuel 2000, 79, 1997-1998. [CrossRef]

45. Park, H.Y.; Ahn, D.H. Gasification kinetics of five coal chars with $\mathrm{CO}_{2}$ at elevated pressure. Korean J. Chem. Eng. 2007, 24, 24-30. [CrossRef]

46. Vyazovkin, S.; Wight, C.A. Model-free and model-fitting approaches to kinetic analysis of isothermal and nonisothermal data. Thermochim. Acta 1999, 340-341, 53-68. [CrossRef]

47. Vyazovkin, S. Computational aspects of kinetic analysis. Part C. The ICTAC Kinetics Project-The light at the end of the tunnel? Thermochim. Acta 2000, 355, 155-163. [CrossRef]

48. Lahijani, P.; Zainal, Z.A.; Mohamed, A.R. Catalytic effect of iron species on $\mathrm{CO}_{2}$ gasification reactivity of oil palm shell char. Thermochim. Acta 2012, 546, 24-31. [CrossRef]

49. Roberts, D.G.; Hodge, E.M.; Harris, D.J.; Stubington, J.F. Kinetics of Char Gasification with $\mathrm{CO}_{2}$ under Regime II Conditions: Effects of Temperature, Reactant, and Total Pressure. Energy Fuels 2010, 24, 5300-5308. [CrossRef]

50. Yuan, S.; Dai, Z.-H.; Zhou, Z.-J.; Chen, X.-L.; Yu, G.-S.; Wang, F.-C. Rapid co-pyrolysis of rice straw and a bituminous coal in a high-frequency furnace and gasification of the residual char. Bioresour. Technol. 2012, 109, 188-197. [CrossRef]

51. Zhang, R.; Wang, Q.H.; Luo, Z.Y.; Fang, M.X.; Cen, K.F. Coal Char Gasification in the Mixture of $\mathrm{H}_{2} \mathrm{O}, \mathrm{CO}_{2}, \mathrm{H}_{2}$, and CO under Pressured Conditions. Energy Fuels 2014, 28, 832-839. [CrossRef]

52. Marquez-Montesinos, F.; Cordero, T.; Rodriguez-Mirasol, J.; Rodriguez, J.J. $\mathrm{CO}_{2}$ and steam gasification of a grapefruit skin char. Fuel 2002, 81, 423-429. [CrossRef]

53. Lopez, G.; Alvarez, J.; Amutio, M.; Arregi, A.; Bilbao, J.; Olazar, M. Assessment of steam gasification kinetics of the char from lignocellulosic biomass in a conical spouted bed reactor. Energy 2016, 107, 493-501. [CrossRef] 
54. Bhatia, S.K.; Perlmutter, D.D. A random pore model for fluid-solid reactions: I. Isothermal, kinetic control. AIChE J. 1980, 26, 379-386. [CrossRef]

55. Lahijani, P.; Zainal, Z.A.; Mohamed, A.R.; Mohammadi, M. Co-gasification of tire and biomass for enhancement of tire-char reactivity in $\mathrm{CO}_{2}$ gasification process. Bioresour. Technol. 2013, 138, 124-130. [CrossRef]

56. Feng, D.; Zhao, Y.; Zhang, Y.; Xu, H.; Zhang, L.; Sun, S. Catalytic mechanism of ion-exchanging alkali and alkaline earth metallic species on biochar reactivity during $\mathrm{CO}_{2} / \mathrm{H}_{2} \mathrm{O}$ gasification. Fuel 2018, 212, 523-532. [CrossRef]

57. Jiang, L.; Hu, S.; Sun, L.-S.; Su, S.; Xu, K.; He, L.-M.; Xiang, J. Influence of different demineralization treatments on physicochemical structure and thermal degradation of biomass. Bioresour. Technol. 2013, 146, 254-260. [CrossRef]

58. González-Vázquez, M.P.; García, R.; Gil, M.V.; Pevida, C.; Rubiera, F. Unconventional biomass fuels for steam gasification: Kinetic analysis and effect of ash composition on reactivity. Energy 2018, 155, 426-437. [CrossRef]

59. Everson, R.C.; Neomagus, H.W.J.P.; Kaitano, R.; Falcon, R.; du Cann, V.M. Properties of high ash coal-char particles derived from inertinite-rich coal: II. Gasification kinetics with carbon dioxide. Fuel 2008, 87, 3403-3408. [CrossRef]

60. Ahmed, I.I.; Gupta, A.K. Kinetics of woodchips char gasification with steam and carbon dioxide. Appl. Energy 2011, 88, 1613-1619. [CrossRef]

61. Fermoso, J.; Gil, M.V.; Borrego, A.G.; Pevida, C.; Pis, J.J.; Rubiera, F. Effect of the Pressure and Temperature of Devolatilization on the Morphology and Steam Gasification Reactivity of Coal Chars. Energy Fuels 2010, 24, 5586-5595. [CrossRef] 